\title{
Identification of bovine leukemia virus tax function associated with host cell transcription, signaling, stress response and immune response pathway by microarray-based gene expression analysis
}

Mariluz Arainga ${ }^{1,2}$, Eri Takeda ${ }^{1}$ and Yoko Aida ${ }^{1,2^{*}}$

\begin{abstract}
Background: Bovine leukemia virus (BLV) is associated with enzootic bovine leukosis and is closely related to human T-cell leukemia virus type I. The Tax protein of BLV is a transcriptional activator of viral replication and a key contributor to oncogenic potential. We previously identified interesting mutant forms of Tax with elevated $\left(\operatorname{Tax}_{\mathrm{D} 247 \mathrm{G}}\right)$ or reduced $\left(\operatorname{Tax}_{\mathrm{S240}}\right.$ ) transactivation effects on BLV replication and propagation. However, the effects of these mutations on functions other than transcriptional activation are unknown. In this study, to identify genes that play a role in the cascade of signal events regulated by wild-type and mutant Tax proteins, we used a large-scale host cell gene-profiling approach.

Results: Using a microarray containing approximately 18,400 human mRNA transcripts, we found several alterations after the expression of Tax proteins in genes involved in many cellular functions such as transcription, signal transduction, cell growth, apoptosis, stress response, and immune response, indicating that Tax protein has multiple biological effects on various cellular environments. We also found that Tax ${ }_{\mathrm{D} 247 \mathrm{G}}$ strongly regulated more genes

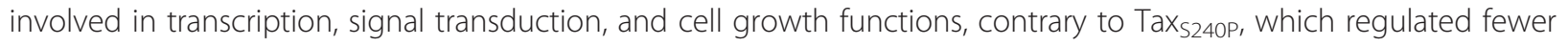
genes. In addition, the expression of genes related to stress response significantly increased in the presence of $\operatorname{Tax}_{\text {S240P }}$ as compared to wild-type Tax and Tax ${ }_{\mathrm{D} 247 \mathrm{G}}$. By contrast, the largest group of downregulated genes was related to immune response, and the majority of these genes belonged to the interferon family. However, no significant difference in the expression level of downregulated genes was observed among the Tax proteins. Finally, the expression of important cellular factors obtained from the human microarray results were validated at the RNA and protein levels by real-time quantitative reverse transcription-polymerase chain reaction and western blotting, respectively, after transfecting Tax proteins into bovine cells and human HeLa cells.
\end{abstract}

Conclusion: A comparative analysis of wild-type and mutant Tax proteins indicates that Tax protein exerts a significant impact on cellular functions as diverse as transcription, signal transduction, cell growth, stress response and immune response. Importantly, our study is the first report that shows the extent to which BLV Tax regulates the innate immune response.

\footnotetext{
* Correspondence: aida@riken.jp

${ }^{1}$ Viral Infectious Diseases Unit, RIKEN, 2-1 Hirosawa, Wako, Saitama 351-0198,

Japan

${ }^{2}$ Laboratory of Viral Infectious Diseases, Department of Medical Genome

Sciences, Graduate School of Frontier Science, The University of Tokyo, Wako,

Saitama 351-0198, Japan
} 


\section{Background}

Bovine leukemia virus (BLV), a retrovirus related to human T-cell leukemia virus types 1 and 2 (HTLV-1 and HTLV-2), causes enzootic bovine leukosis, a disease characterized by a very extended course that often involves persistent lymphocytosis (PL) and culminates in B-cell lymphoma [1]. BLV encodes the regulatory proteins Tax and Rex, which contribute to infectious potential and the regulation of viral expression [2,3]. The Tax protein acts on a triplicate 21-bp enhancer motif known as the Taxresponsive element (TxRE) in the $\mathrm{U} 3$ region of the 5 'long terminal repeat (LTR), and it stimulates transactivation of the viral genome $[2,4]$. The TxRE consists of a cyclic AMP-response element (CRE)-like sequence, and Tax has been suggested to bind indirectly to this element through cellular factors, such as members of the CREB/ activating transcription factor (ATF) family of basic leucine zipper proteins that have been shown to bind to the CRE-like sequence [5-7]. The Tax protein is also known to modulate the expression of cellular genes that are related to the regulation of cell growth [8]. Tax induces the immortalization of primary rat embryo fibroblasts and cooperates with the Ha-ras oncogene to induce the full transformation of cells that form tumors when injected into nude mice, a property shared by the G4 protein of BLV $[9,10]$. Furthermore, the expression of Tax in primary ovine B lymphocytes, which depends on CD154 and interleukin-4, affects B lymphocyte proliferation, cell cycle phase distribution, and survival, leading to cytokine-independent growth [11]. This immortalization process is also correlated with increased $\mathrm{Bcl}-2$ protein levels, nuclear NF-kB accumulation, and a series of intracellular pathways that remain to be characterized [12]. In addition, Tax BLV inhibits base-excision DNA repair of oxidative damage, potentially increasing the accumulation of ambient mutations in cellular DNA [13]. To further understand the mechanisms of action, the identification of Tax-associated host cellular factors and pathways is now essential.

Our group has previously identified a Tax mutant in BLV that stimulates viral LTR-directed transcription via the BLV enhancer, and the extent of stimulation by this mutant is significantly greater than that of wild-type Tax and also that of a defective mutant that lacks this capacity [14]. The mutants have missense mutations in residues $247\left(\operatorname{Tax}_{\mathrm{D} 247 \mathrm{G}}\right)$ and $240\left(\operatorname{Tax}_{\mathrm{S} 240 \mathrm{P}}\right)$ that confer high and defective transactivation ability to the mutants, respectively [14]. Furthermore, it has been shown that $\operatorname{Tax}_{\mathrm{D} 247 \mathrm{G}}$ but not wild-type Tax protein activates the upstream sequence of the human cellular proto-oncogene c-fos, which contains 2 major cis-acting elements-the CArG box and CRE motif indispensable for the activation of $c$-fos by the mutant Tax protein-and also increases the levels of endogenous c-fos mRNA considerably in both human and bovine cell lines [8], suggesting that $\operatorname{Tax}_{\mathrm{D} 247 \mathrm{G}}$ might have the ability to activate the production of virus particles and an enhanced ability to induce leukemia/lymphosarcoma compared with wild-type Tax protein. Interestingly, we observed that an infectious molecular clone of BLV that encodes the $\operatorname{Tax}_{\mathrm{D} 247 \mathrm{G}}$ protein produced more viral particles and was transmitted at an elevated rate in vitro, but with no significant differences in the viral load and the expression of viral RNA between sheep experimentally injected with BLVs that encode the wild-type and mutant $\operatorname{Tax}_{\mathrm{D} 247 \mathrm{G}}$ proteins [15], suggesting a possible mechanism for regulating BLV-LTR-directed transcription by Tax that may play an important role in viral silencing in vivo. In addition, it appears that Tax protein has the capacity to participate in the induction and inhibition of cell survival in vitro and ex vivo, respectively, and mutant Tax protein caused greater stimulation than wild-type Tax protein did $[16,17]$. The enhanced activity of such a mutant Tax protein might be due to alterations in the interactions between Tax and cellular factors owing to the change in the amino acid sequence between amino acids 240 and 265 . However, the mechanism by which such mutations increase the activity of Tax and the cellular factors involved in this process remains unknown.

The advent of microarray technology, coupled with the availability of comprehensive databases of gene identity and function, has made it possible to examine transcriptional changes across a landscape of thousands of genes. The human genome is almost fully annotated, and thus, chips representing all of the annotated genes are commercially available. By contrast, the quality of commercially and custom-made genome-wide microarrays is still poor because of the limited availability of full-length cDNA sequences in cattle. In this study, in an attempt to identify genes that play a role in the cascade of signal events regulated by wild-type $\operatorname{Tax}\left(\operatorname{Tax}_{\mathrm{WT}}\right)$ and mutant Tax with high $\left(\operatorname{Tax}_{\mathrm{D} 247 \mathrm{G}}\right)$ and defective transactivation activity $\left(\operatorname{Tax}_{\mathrm{S} 240 \mathrm{P}}\right)$, we used a large-scale host cell gene-profiling approach using human cDNA microarrays. Furthermore, we chose human HeLa cells, which have been extensively characterized regarding the host factors involved in various cellular functions as a model system for analysis of bovine Tax proteins; isolated total RNA from HeLa cells had been transfected with expression vectors encoding $\operatorname{Tax}_{\mathrm{WT}}, \operatorname{Tax}_{\mathrm{S} 240 \mathrm{~B}} \operatorname{Tax}_{\mathrm{D} 247 \mathrm{G}}$, or control vector; and subjected each RNA sample to human microarray analysis. The genomic expression profiling resulted in the identification of approximately 300 genes up- and downregulated by wild-type and mutant Tax proteins. Finally, the expression of important transcriptional cellular factors indicated by the human microarray results were validated after the transfection of wild-type or mutant Tax proteins into bovine cells as well as human HeLa cells. 


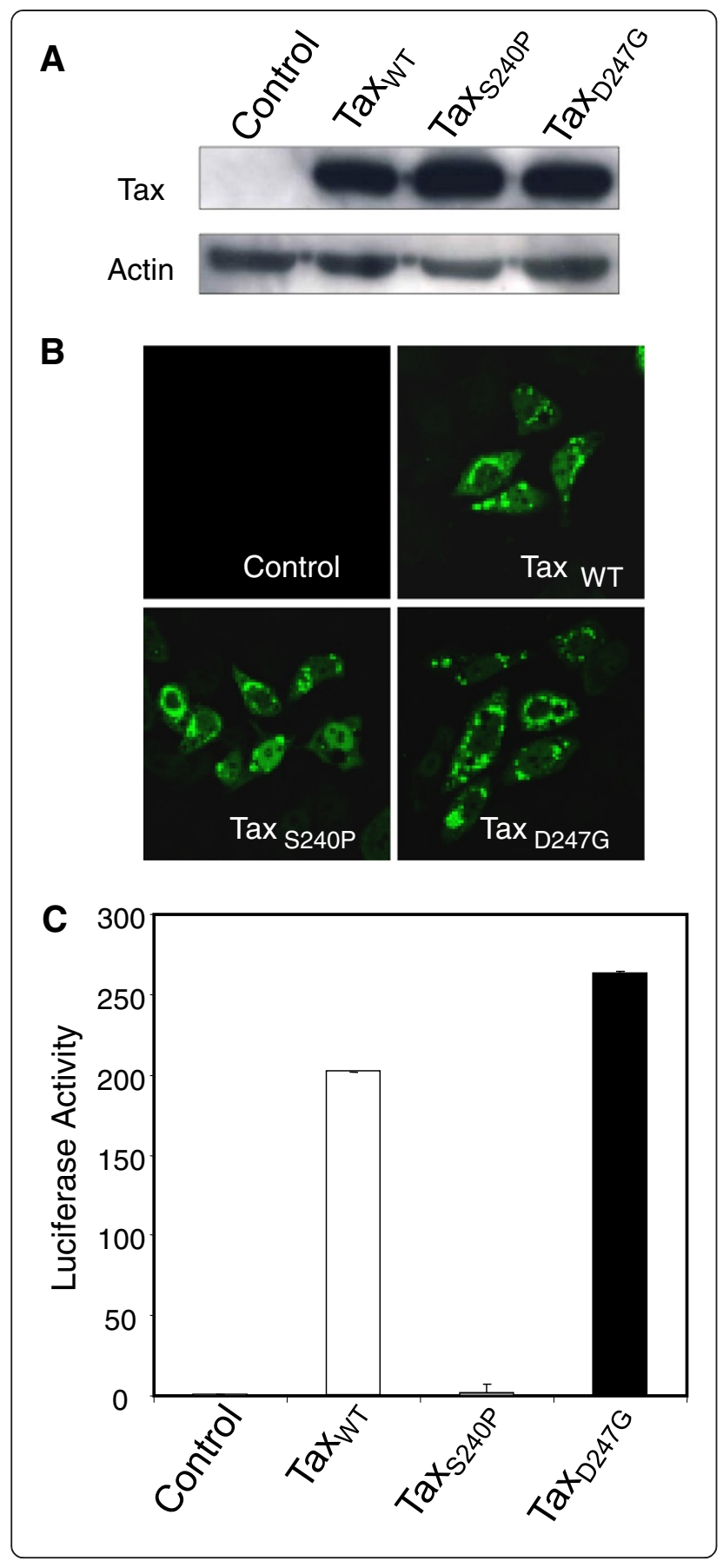

Figure 1 Expression, localization, and transactivation of wildtype and mutant Tax proteins in HeLa cells. HeLa cells were transfected with pCAGGS encoding Flag-tagged Tax proteins

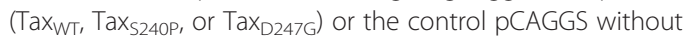
(A and $\mathbf{B}$ ) or with the reporter plasmid pGV-BLTR and the reference plasmid pRL-SV40 (C). Thereafter, $24 \mathrm{~h}$ after transfection, cells were subjected to western blotting (A), confocal laser-scanning analysis (B), and the firefly luciferase assay (C). (A) Western blotting was performed using an anti-Flag M2 MAb and anti-actin antibody as a control. (B) For immunofluorescence, cells were fixed, permeabilized, and immunostained with anti-Flag M2 MAb followed by the Alexa-488-conjugated anti-mouse antibody (green). (C) For the transactivation assay, cells were recovered and lysed, and the activities of firefly and Renilla luciferase were measured. For each sample, the firefly luciferase activity (pGV-BLTR) was normalized by reference to Renilla luciferase activity (pRL-SV40). Average values from triplicate transfections with standard deviations (error bars) are shown $\left({ }^{*} p<0.01\right)$

\section{Results}

Expression of wild-type and mutant tax proteins in HeLa cells

To measure alterations in the expression of host cellular genes regulated by wild-type and mutant Tax proteins with elevated (D247G) and reduced (S240P) transactivation activity, we constructed pCAGGS mammalian expression vectors encoding Tax proteins $\left(\operatorname{Tax}_{\mathrm{WT}}, \mathrm{Tax}_{\mathrm{S} 240 \mathrm{~B}}\right.$ and $\operatorname{Tax}_{\mathrm{D} 247 \mathrm{G}}$ ) that were Flag-tagged at their carboxy termini to facilitate the assay, and these vectors were transfected into human cervical HeLa cells. At $24 \mathrm{~h}$ after transfection, we examined the expression of each Tax protein by western blotting using monoclonal antibody (MAb) M2, which recognizes the Flag tag (Figure $1 \mathrm{~A}$ ). We observed a single band for each of the 3 vector constructs, and found no difference in protein expression between wild-type and mutant Tax proteins in repeated experiments. As shown in Figure 1B, all Tax proteins exhibited greater cytoplasmic localization than nuclear localization and exhibited punctate staining patterns in the majority of transfected HeLa cells, as previously described by [18]. To clarify the transactivation capacity of mutant Tax proteins, we transfected HeLa cells with Tax expression vectors plus the reporter plasmid pGV-BLTR, which expressed the full-length BLV LTR upstream of the luciferase gene, and then, we analyzed the luciferase activity (Figure 1C). Tax ${ }_{\mathrm{D} 247 \mathrm{G}}$ was able to induce higher viral LTR-directed transcriptional activation than the $\mathrm{Tax}_{\mathrm{WT}}$, in contrast to $\mathrm{Tax}_{\mathrm{S} 240 \mathrm{P}}$ which markedly reduced this activity, in line with the result of our previous study using 293 T cells [14]. Thus, we confirmed that there was no obvious relationship between transactivation activity and the expression, stability, and localization of Tax proteins in HeLa cells. Therefore, we used HeLa cells in subsequent microarray experiments. 
Figure 2 Differential expression of cellular genes after induction of wild-type and mutant Tax proteins in HeLa cells. Total RNA from HeLa cells transfected with pCAGGS encoding Tax proteins ( $\operatorname{Tax}_{W T}, T_{a} 240 p$, or $\operatorname{Tax}_{\mathrm{D} 247 \mathrm{G}}$ ) or the control pCAGGS was used for the microarray analysis. (A) Heat map of hierarchical gene clustering. The microarray data was analyzed using GeneSpring GX 11.0 software to obtain the hierarchical clustering. The columns correspond to gene profiles regulated by the different Tax proteins indicated above the map. Below the heat map is a color-coded scale bar for the relative expression levels of genes. (B) Number of genes significantly up- or downregulated by wild-type and mutant Tax proteins. The genes shown in this figure passed 2 filtering criteria: (1) statistical significance $(p<0.05)$ and (ii) at least 2-fold changes in the expression of a cellular gene at least 1 time point.

Large-scale expression profiling of cellular genes after the transfection of wild-type and mutant tax proteins

To analyze the transcriptional effects by wild-type and mutant Tax proteins on global gene expression, total RNA was isolated from HeLa cells that had been transfected with $\operatorname{Tax}_{\mathrm{WT}}$, $\operatorname{Tax}_{\mathrm{S} 240 \mathrm{~B}} \operatorname{Tax}_{\mathrm{D} 247 \mathrm{G}}$, or control vector, and each RNA sample was subjected to microarray analysis. Additionally, to ensure equivalent transfection efficiency, we simultaneously assessed the expression of all Tax proteins and confirmed same efficiency in our samples (data not shown). After microarray analysis, data sets were analyzed using GeneSpring GX 11.0 software for gene expression, clustering, gene ontology, and significant pathway signaling. Using DNA microarrays containing approximately 18,400 mRNA transcripts in each array, we identified over 300 genes hierarchically clustered for all samples (Figure 2A). Among them, 122 (90 were upregulated and 32 were downregulated), 118 (64 were upregulated and 54 were downregulated), and 139 genes (95 were upregulated and 44 were downregulated) exhibited statistically significant differential regulation (2-fold or more) by $\mathrm{Tax}_{\mathrm{WT}}$, $\operatorname{Tax}_{\mathrm{S} 240 \mathrm{~B}}$ and $\mathrm{Tax}_{\mathrm{D} 247 \mathrm{G}}$, respectively $(\mathrm{p}<0.05)$ (Figure $2 \mathrm{~B}$ ). The mutant $\mathrm{Tax}_{\mathrm{S} 240 \mathrm{P}}$ induced more variation in whole gene expression, as noted by the colors in the heat map (Figure 2A), which indicated that this mutant upregulated (red) fewer genes and downregulated (blue) more genes than the other Tax proteins did. The numbers of genes up- and downregulated by $\operatorname{Tax}_{\mathrm{WT}}$ or $\operatorname{Tax}_{\mathrm{D} 247 \mathrm{G}}$ were similar, but the intensity of the expression changes was slightly stronger in the case of $\operatorname{Tax}_{\mathrm{D} 247 \mathrm{G}}$.

Analysis of gene ontology annotations revealed the number of genes grouped according to biological functions that were upregulated by wild-type and mutant Tax proteins by at least 2 -fold $(\mathrm{p}<0.05)$ (Figure 3$)$. The upregulated genes were clustered within functional groups involved in transcription/translation/RNA processing, cell growth/proliferation, signal transduction, transport, phosphorylation, apoptosis, stress response, metabolic processes, and cell adhesion. Interestingly, we found that 


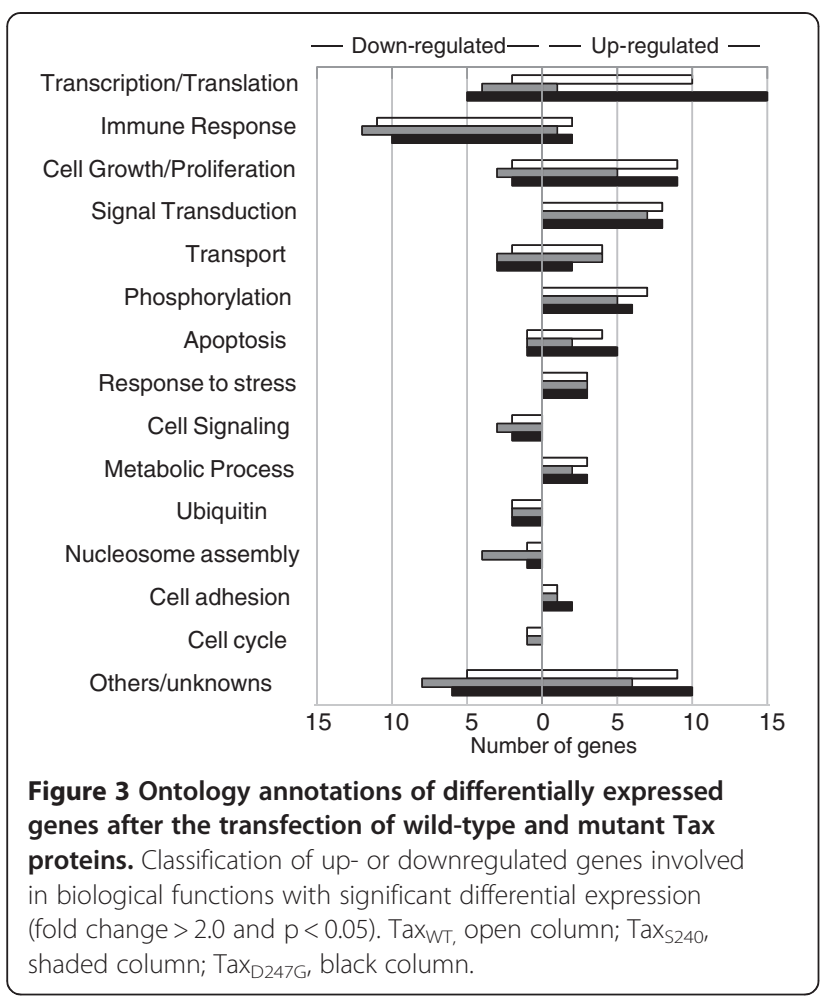

$\operatorname{Tax}_{\mathrm{D} 247 \mathrm{G}}$ regulated more genes involved in transcription/ translation/RNA processing functions, contrary to $\mathrm{Tax}_{\mathrm{S} 240 \mathrm{~B}}$, which regulated fewer genes (Figure 3). As shown in Table 1, $\operatorname{Tax}_{\mathrm{D} 247 \mathrm{G}}$ induced higher expression for the following genes than Tax $\mathrm{WT}_{\mathrm{WT}}$ and Tax $\mathrm{T}_{\mathrm{S} 240 \mathrm{P}}$ did: genes involved in transcription/translation/RNA processing such as CREM, FOS, NR4A2, RORA, MAFB, and MAFF; genes involved in signal transduction such as GEM, GNB5, PITPNC1, RGS5, and RRAD; genes involved in cell growth/cell proliferation such as CYR61, EMP3, and IL11; TNFAIP6, which is involved in immune responses; NPTX1, which is involved in transport; PHLDA1, which is involved in apoptosis; and DUSP1, which is a dual specificity serine/threonine phosphatase. All these genes were expressed at lower level in cells transfected with Tax ${ }_{\mathrm{S} 240 \mathrm{~B}}$ which indicated the reduced transactivation activity of $\operatorname{Tax}_{\mathrm{S} 240 \mathrm{P}}$ compared to that of $\operatorname{Tax}_{\mathrm{WT}}$ or $\operatorname{Tax}_{\mathrm{D} 247 \mathrm{G}}$. By contrast, the expression of DNAJB1, HSPA1A, and HSPA6, which respond to stress, was significantly increased in the presence of $\mathrm{Tax}_{\mathrm{S} 240 \mathrm{P}}$ compared to that in the presence of the other Tax proteins. There were no differences in the expression levels of genes related to apoptosis, such as IER3, TNFRSF12A, and NFRSF21; genes related to transcription/translation/RNA processing, such as ETV5 and JUN; and genes related to signal transduction, such as GDF15, induced by the Tax proteins. Thus, we confirmed that our mutant $\operatorname{Tax}_{\mathrm{D} 247 \mathrm{G}}$ strongly induced the expression of cellular factors involved in transcription/translation/
RNA processing, signal transduction, and cell growth/cell proliferation, whereas the mutant $\mathrm{Tax}_{\mathrm{S} 240 \mathrm{P}}$ could not induce these genes at high expression levels. Our result also shows that the mutant $\mathrm{Tax}_{\mathrm{S} 240 \mathrm{P}}$ upregulated genes related to stress responses.

We next assessed whether the expression of wildtype and mutant Tax proteins resulted in the transcriptional downregulation of any cellular transcripts. The downregulated genes were involved in transcription/ translation/RNA processing, immune response, cell growth/proliferation, apoptosis, cell cycle, transport, cell signaling, ubiquitination, and nucleosome assembly (Figure 3). In particular, a number of molecules involved in immune response were significantly downregulated by all of the Tax proteins. As shown in Table 2, we found 12 downregulated genes involved in immune response and the immune response to virus infection, and interestingly, they were mainly related to the interferon family of anti-viral factors, such as IFIT1, IFIT3, and OASL. In general, the expression levels of the downregulated genes were similarly affected by the 3 Tax proteins. Thus, our results clearly demonstrated a significant negative impact of Tax on expression of genes involved in the innate immune response to viral infection.

Moreover, we determined which biological pathways and genes involved in these pathways were significantly affected by wild-type and mutant Tax proteins $(\mathrm{p}<0.05)$ (Table 3$)$. Almost all the pathways were represented by the same genes regulated by all of our Tax constructs, and these pathways and genes are involved in many transcriptional functions, such as p53 effectors, transcriptional targets of AP1 family, IL1-mediated signaling, regulation of p38 MAPK signaling, IL12-mediated signaling, IL2-mediated signaling, ATF-2 transcription factor network, JNK signaling in the CD4+ TCR pathway, and Ras signaling in the CD4+ TCR pathway (Table 3).

\section{Validation of the expression of host cellular genes at the RNA and protein levels in HeLa cells}

To validate the microarray data after overexpression of wild-type and mutant Tax proteins in HeLa cells, we assessed the expression of several transcriptional cellular factors at the RNA and protein levels (Figure 4). First, real-time quantitative reverse transcription-polymerase chain reaction (qRT-PCR) was used to corroborate the fold changes obtained from the microarray results. In performing this assay, we chose significantly upregulated genes in 4 categories: transcription/translation/RNA processing (FOS, JUN, NR4A2, and RORA), signal transduction (GEM and RRAD), immune response (TNFAIP6), and regulation of cell growth and cell proliferation (CYR61). The qRT-PCR results for these genes in HeLa cells that had been transfected with pCAGGS encoding $\operatorname{Tax}_{\mathrm{WT}}, \operatorname{Tax}_{\mathrm{S} 240 \mathrm{~B}}$ or $\operatorname{Tax}_{\mathrm{D} 247 \mathrm{G}}$, are presented in Figure 4. 
Table 1 Genes upregulated in the total RNA fraction in the presence of wild-type and mutant Tax proteins

\begin{tabular}{|c|c|c|c|c|c|}
\hline \multirow[t]{2}{*}{ Gene ID } & \multirow[t]{2}{*}{ Gene description } & \multirow{2}{*}{$\begin{array}{l}\text { Gene } \\
\text { Symbol }\end{array}$} & \multicolumn{3}{|c|}{ Fold Change } \\
\hline & & & $\overline{\operatorname{Tax}_{\mathrm{WT}}}$ & $\operatorname{Tax}_{\mathbf{S 2 4 0 P}}$ & $\operatorname{Tax}_{\mathrm{D24G}}$ \\
\hline & Transcription/Translation/RNA processing & & & & \\
\hline 1390 & CAMP responsive element modulator & CREM & 2.2 & 1.8 & 3.2 \\
\hline 1958 & early growth response 1 & EGR1 & 1.9 & 2.0 & 1.7 \\
\hline 22936 & elongation factor, RNA polymerase II, 2 & ELL2 & 2.2 & 2.2 & 2.2 \\
\hline 2119 & ets variant 5 & ETV5 & 3.7 & 3.6 & 3.4 \\
\hline 2353 & FBJ murine osteosarcoma viral oncogene homolog & FOS & 3.7 & 2.4 & 4.6 \\
\hline 8061 & FOS-like antigen 1 & FOSL1 & 2.4 & 2.4 & 2.3 \\
\hline 3280 & Hairy and enhancer of split 1 (Drosophila) & HES1 & 1.8 & 1.9 & 2.0 \\
\hline 3725 & jun oncogene & $J U N$ & 4.7 & 5.9 & 5.3 \\
\hline 10365 & Kruppel-like factor 2 (lung) & KLF2 & 2.6 & 2.6 & 2.8 \\
\hline 1316 & Kruppel-like factor 6 & KLF6 & 2.1 & 2.1 & 2.1 \\
\hline 9935 & v-maf musculoaponeurotic fibrosarcoma oncogene homolog B (avian) & MAFB & 2.6 & 1.9 & 3.8 \\
\hline 23764 & v-maf musculoaponeurotic fibrosarcoma oncogene homolog F (avian) & MAFF & 2.4 & 1.9 & 2.6 \\
\hline 4929 & nuclear receptor subfamily 4, group A, member 2 & NR4A2 & 3.6 & 1.5 & 7.7 \\
\hline 57157 & Putative homeodomain transcription factor 2 & PHTF2 & 1.9 & 1.9 & 2.0 \\
\hline 6095 & RAR-related orphan receptor A & RORA & 10.3 & 2.0 & 10.6 \\
\hline \multirow[t]{2}{*}{7538} & zinc finger protein $36, \mathrm{C} 3 \mathrm{H}$ type, homolog (mouse) & ZFP36 & 2.8 & 2.6 & 2.6 \\
\hline & Signal Transduction & & & & \\
\hline 287 & ankyrin 2, neuronal & ANK2 & 2.0 & 2.0 & 1.4 \\
\hline 9518 & growth differentiation factor 15 & GDF15 & 5.0 & 4.9 & 5.6 \\
\hline 2669 & GTP binding protein over expressed in skeletal muscle & GEM & 14.3 & 5.0 & 19.1 \\
\hline 10681 & guanine nucleotide binding protein ( $G$ protein), beta 5 & GNB5 & 2.0 & 1.2 & 2.4 \\
\hline 2786 & guanine nucleotide binding protein ( $G$ protein), gamma 4 & GNG4 & 1.8 & 2.0 & 1.6 \\
\hline 26207 & phosphatidylinositol transfer protein, cytoplasmic 1 & PITPNC1 & 1.9 & 1.7 & 2.5 \\
\hline 5329 & plasminogen activator, urokinase receptor & PLAUR & 2.0 & 1.7 & 1.9 \\
\hline 5521 & protein phosphatase 2 (formerly $2 A$ ), regulatory subunit $B$, beta isoform & PPP2R2B & 1.3 & 1.0 & 2.1 \\
\hline 5997 & regulator of G-protein signaling 2, $24 \mathrm{kDa}$ & RGS2 & 2.4 & 1.1 & 2.4 \\
\hline 6004 & regulator of G-protein signaling 16 & RGS16 & 2.0 & 2.0 & 2.0 \\
\hline 6236 & Ras-related associated with diabetes & RRAD & 3.8 & 2.3 & 7.9 \\
\hline \multirow[t]{2}{*}{81848} & sprouty homolog 4 (Drosophila) & SPRY4 & 1.9 & 2.1 & 1.9 \\
\hline & Inflammatory response/Immune response & & & & \\
\hline 2921 & chemokine ( $\mathrm{C}-\mathrm{X}-\mathrm{C}$ motif) ligand 3 & CXCL3 & 1.8 & 2.0 & 1.8 \\
\hline 3269 & histamine receptor $\mathrm{H} 1$ & $\mathrm{HRH} 1$ & 2.5 & 1.7 & 1.8 \\
\hline \multirow[t]{2}{*}{7130} & tumor necrosis factor, alpha-induced protein 6 & TNFAIP6 & 20.5 & 1.3 & 36.6 \\
\hline & Regulation of cell growth/Regulation of cell proliferation & & & & \\
\hline 183 & angiotensinogen (serpin peptidase inhibitor, clade A, member 8) & AGT & 1.3 & 1.3 & 2.3 \\
\hline 374 & amphiregulin & AREG & 2.0 & 2.1 & 2.3 \\
\hline 694 & B-cell translocation gene 1, anti-proliferative & BTG1 & 3.3 & 1.1 & 3.0 \\
\hline 6347 & chemokine (C-C motif) ligand 2 & CCL2 & 2.0 & 1.6 & 1.6 \\
\hline 960 & CD44 molecule (Indian blood group) & CD44 & 2.1 & 2.0 & 2.3 \\
\hline 3491 & cysteine-rich, angiogenic inducer, 61 & CYR61 & 4.8 & 2.0 & 7.5 \\
\hline 2014 & epithelial membrane protein 3 & EMP3 & 1.8 & 1.2 & 3.1 \\
\hline
\end{tabular}


Table 1 Genes upregulated in the total RNA fraction in the presence of wild-type and mutant Tax proteins (Continued)

\begin{tabular}{|c|c|c|c|c|c|}
\hline 3589 & interleukin 11 & IL11 & 3.6 & 1.7 & 5.4 \\
\hline 83729 & inhibin, beta $\mathrm{E}$ & INHBE & 2.1 & 3.0 & 1.9 \\
\hline 182 & jagged 1 & JAG1 & 2.1 & 1.8 & 2.3 \\
\hline \multirow[t]{2}{*}{3976} & leukemia inhibitory factor (cholinergic differentiation factor) & LIF & 2.2 & 2.2 & 2.2 \\
\hline & Apoptosis & & & & \\
\hline 56892 & chromosome 8 open reading frame 4 & C8orf4 & 1.2 & 1.2 & 2.3 \\
\hline 8870 & immediate early response 3 & IER3 & 3.3 & 3.2 & 3.7 \\
\hline 22822 & pleckstrin homology-like domain, family A, member 1 & PHLDA1 & 2.5 & 1.9 & 3.2 \\
\hline 51330 & tumor necrosis factor receptor superfamily, member $12 \mathrm{~A}$ & TNFRSF12A & 2.0 & 1.9 & 2.0 \\
\hline \multirow[t]{2}{*}{27242} & tumor necrosis factor receptor superfamily, member 21 & TNFRSF21 & 2.3 & 2.1 & 2.4 \\
\hline & Cell adhesion/Cell-cell adhesion & & & & \\
\hline 6695 & sparc/osteonectin, cwcv and kazal-like domains proteoglycan 1 & SPOCK1 & 2.0 & 1.7 & 2.1 \\
\hline \multirow[t]{2}{*}{6696} & secreted phosphoprotein 1 & SPP1 & 1.9 & 2.5 & 2.1 \\
\hline & Transport & & & & \\
\hline 3039 & hemoglobin, alpha 1 & HBA1 & 2.4 & 2.5 & 2.4 \\
\hline 4884 & neuronal pentraxin I & NPTX1 & 2.3 & 1.2 & 3.6 \\
\hline 6507 & solute carrier family 1, member 3 & SLC1A3 & 1.8 & 2.0 & 1.8 \\
\hline 6533 & solute carrier family 6 , member 6 & SLC6A6 & 2.2 & 2.3 & 1.9 \\
\hline \multirow[t]{2}{*}{23657} & solute carrier family 7, member 11 & SLC7A11 & 2.3 & 2.4 & 1.8 \\
\hline & Metabolic process & & & & \\
\hline 384 & arginase, type ॥ & ARG2 & 3.2 & 3.2 & 3.6 \\
\hline 9945 & glutamine-fructose-6-phosphate transaminase 2 & GFPT2 & 2.0 & 2.0 & 1.9 \\
\hline 9388 & Lipase, endothelial & LIPG & 1.9 & 1.4 & 2.1 \\
\hline \multirow[t]{2}{*}{7378} & uridine phosphorylase 1 & UPP1 & 2.1 & 1.8 & 2.0 \\
\hline & Phosphorylation/Dephosphorylation & & & & \\
\hline 9201 & doublecortin-like kinase 1 & DCLK1 & 2.1 & 2.0 & 2.1 \\
\hline 1843 & dual specificity phosphatase 1 & DUSP1 & 3.6 & 2.4 & 4.7 \\
\hline 51207 & dual specificity phosphatase 13 & DUSP13 & 2.2 & 1.9 & 2.2 \\
\hline 1846 & dual specificity phosphatase 4 & DUSP4 & 2.9 & 3.0 & 2.9 \\
\hline 1847 & dual specificity phosphatase 5 & DUSP5 & 2.4 & 2.4 & 2.8 \\
\hline 1848 & dual specificity phosphatase 6 & DUSP6 & 2.4 & 2.8 & 2.7 \\
\hline \multirow[t]{2}{*}{5578} & protein kinase $\mathrm{C}$, alpha & PRKCA & 2.1 & 1.9 & 1.8 \\
\hline & Response to stress & & & & \\
\hline 3337 & DnaJ (Hsp40) homolog, subfamily B, member 1 & DNAJB1 & 2.7 & 3.1 & 2.5 \\
\hline 3303 & heat shock $70 \mathrm{kDa}$ protein $1 \mathrm{~A}$ & HSPA1A & 2.9 & 4.2 & 2.8 \\
\hline \multirow[t]{2}{*}{3310} & heat shock 70 kDa protein 6 & HSPA6 & 6.4 & 15.4 & 5.3 \\
\hline & Others/Unknown & & & & \\
\hline 202 & absent in melanoma 1 & AlM1 & 1.7 & 1.8 & 2.1 \\
\hline 23237 & activity-regulated cytoskeleton-associated protein & ARC & 2.5 & 2.3 & 2.3 \\
\hline 1475 & cystatin A (stefin A) & CSTA & 4.6 & 5.3 & 5.4 \\
\hline 56603 & cytochrome P450, family 26, subfamily B, polypeptide 1 & CYP26B1 & 2.1 & 1.7 & 2.1 \\
\hline 23052 & endonuclease domain containing 1 & ENDOD1 & 2.0 & 2.1 & 2.1 \\
\hline 2201 & fibrillin 2 & FBN2 & 2.1 & 1.6 & 1.8 \\
\hline 10324 & kelch repeat and BTB (POZ) domain containing 10 & KBTBD10 & 3.0 & 1.9 & 2.4 \\
\hline
\end{tabular}


Table 1 Genes upregulated in the total RNA fraction in the presence of wild-type and mutant Tax proteins (Continued)

\begin{tabular}{|c|c|c|c|c|c|}
\hline 5270 & serpin peptidase inhibitor, clade $\mathrm{E}$, member 2 & SERPINE2 & 2.3 & 2.3 & 2.4 \\
\hline 4071 & transmembrane $4 \mathrm{~L}$ six family member 1 & TM4SF1 & 1.9 & 1.8 & 2.3 \\
\hline 25907 & transmembrane protein 158 (gene/pseudogene) & TMEM158 & 2.1 & 2.4 & 2.5 \\
\hline 7171 & tropomysin 4 & TPM4 & 2.5 & 1.5 & 3.5 \\
\hline 7846 & tubulin, alpha 1a & TUBA1A & 1.9 & 2.1 & 1.8 \\
\hline
\end{tabular}

Representative qRT-PCR data were consistent with the data of microarrays in 7 validated cases (FOS, NR4A2, RORA, GEM, RRAD, TNFAIP6, and CYR61) in which $\operatorname{Tax}_{\mathrm{D} 247 \mathrm{G}}$ induced higher gene expression than $\operatorname{Tax}_{\mathrm{WT}}$ and Tax $_{\text {S240P }}$ did and in 1 validated case (JUN) in which the gene expression was similar for all 3 Tax proteins. However, the fold expression of the TNFAIP6 gene observed by the microarray analysis was higher than that in the qRT-PCR analysis. For instance, according to the microarray analysis, TNFAIP6 expression was upregulated 20.5-, 1.3-, and 36.6-fold in the presence of Tax $\mathrm{TWT}_{\mathrm{W}}$, Tax $\mathrm{Tan}_{\mathrm{S} 240 \mathrm{~B}}$ and $\mathrm{Tax}_{\mathrm{D} 247 \mathrm{G}}$, respectively, compared with 5-, 2-, and 8-fold according to qRT-PCR. These qRT-PCR results confirmed that $\operatorname{Tax}_{\mathrm{D} 247 \mathrm{G}}$ induced strong responses of genes, whereas $\mathrm{Tax}_{\mathrm{S} 240 \mathrm{P}}$ induced the weakest responses among the 3 Tax proteins.

We next validated the results of the genes that were downregulated in Tax-expressing HeLa cells. For this purpose, we selected genes related to transcription/ translation/RNA processing (ID2), immune response/ response to virus (IFIT1 and IFIT3), and apoptosis (TNFSF10). As shown in Figure 4B, the expression of all of these genes were very low in the presence of Tax proteins, and there were no differences in the expression of these genes in the presence of wild-type and mutant Tax proteins, which perfectly correlated with our microarray results.

Finally, to further confirm that the changes observed at the RNA level were consistent at the protein level, we used western blotting to determine the expression of FOS, RORA, GEM, RRAD, TNFAIP6, and Actin as a control (Figure 4C). The results from this analysis indicate that Tax induced the overexpression of FOS, RORA, GEM, RRAD, and TNFAIP6; however, in the case of FOS, GEM, and TNFAIP6, the expression was higher in the presence of $\operatorname{Tax}_{\mathrm{WT}}$ or $\operatorname{Tax}_{\mathrm{D} 247 \mathrm{G}}$ than in the presence of $\mathrm{Tax}_{\mathrm{S} 240 \mathrm{P}}$. However, $\mathrm{Tax}_{\mathrm{S} 240 \mathrm{P}}$ did not induce the overexpression of TNFAIP6. RRAD was highly overexpressed in the presence of $\operatorname{Tax}_{\mathrm{D} 247 \mathrm{G}}$, but there was no difference between the expression induced by $\operatorname{Tax}_{\mathrm{WT}}$ and that induced by $\mathrm{Tax}_{\mathrm{S} 240 \mathrm{P}}$. By contrast, all of our Tax proteins induced similar levels of RORA expression. In general, all of these results were in agreement with the microarray results in HeLa cells, supporting the authenticity of our microarray data.
Validation of the expression of host cellular genes at the RNA and protein levels in bovine 23 CLN cells

Because our microarray analysis was performed in human cells and human arrays, we determined whether similar results could be obtained in bovine cells, the natural host for BLV. Therefore, we used bovine lymph node 23CLN cells for the purpose of this study. First, to detect protein expression and localization in 23CLN cells, pCAGGS vectors encoding Tax proteins were transfected into 23CLN cells, and then, the cells were subjected to confocal laserscanning analysis and western blotting. As shown in Figure $5 \mathrm{~A}$, all 3 proteins localized predominantly to the cytoplasm, with lesser amounts detected in the nucleus, as observed for HeLa cells (Figure 1A). Western blotting analysis with the MAb M2 revealed that each Tax protein was expressed at detectable levels in the corresponding transfected 23CLN cells (Figure 5D). Moreover, Tax ${ }_{W T}$ and $\operatorname{Tax}_{\mathrm{D} 247 \mathrm{G}}$ were able to induce higher viral LTRdirected transcriptional activation than $\operatorname{Tax}_{\mathrm{S} 240 \mathrm{P}}$ (data not shown), similarly as observed in HeLa cells.

Later, we examined in Tax-expressing bovine cells the expression levels of factors, FOS, JUN, NR4A2, RORA, GEM, RRAD, TNFAIP6, and CYR61 genes, confirmed as being upregulated in Tax-expressing HeLa cells by qRTPCR in Figure 4A (Figure 5B). It is important to mention that FOS and JUN were highly overexpressed in bovine cells compared to its expression in human cells. By contrast, it should also be noted that RORA, GEM, RRAD and TNFAIP6 genes which showed significantly high gene expression in human cells, were only slightly upregulated in 23CLN cells. Furthermore, four genes, ID2, IFIT1, IFIT3 and TNFSF10, were downregulated in the presence of Tax in 23CLN cells in accordance to our microarray data in HeLa cells; but surprisingly, only Tax ${ }_{\text {WT }}$ up-regulated the expression of IFIT3 with the two-hold increase as compared to the control sample (Figure 5C), indicating that only $\mathrm{Tax}_{\mathrm{WT}}$ induced the upregulation of expression of this gene related to immune response/response to virus in 23CLN cells. Finally, Western blotting with polyclonal antibodies against FOS, RRAD and TNFAIP6 showed the overexpression of these proteins in the presence of Tax in 23CLN cells and noticed that FOS expression was higher in the presence of $\operatorname{Tax}_{\mathrm{WT}}$ or $\operatorname{Tax}_{\mathrm{D} 247 \mathrm{G}}$ than compared with the presence of $\operatorname{Tax}_{\mathrm{S} 240 \mathrm{P}}$ and RRAD and TNFAIP6 were mainly 
Table 2 Genes downregulated in the total RNA fraction in the presence of wild-type and mutant Tax proteins

\begin{tabular}{|c|c|c|c|c|c|}
\hline \multirow[t]{2}{*}{ Gene ID } & \multirow[t]{2}{*}{ Gene description } & \multirow{2}{*}{$\begin{array}{l}\text { Gene } \\
\text { Symbol }\end{array}$} & \multicolumn{3}{|c|}{ Fold Change } \\
\hline & & & $\overline{\operatorname{Tax}_{\mathrm{WT}}}$ & $\operatorname{Tax}_{\mathrm{S} 240 \mathrm{P}}$ & $\operatorname{Tax}_{\mathrm{D} 247 \mathrm{G}}$ \\
\hline & Transcription/Translation/RNA processing & & & & \\
\hline 23741 & EP300 interacting inhibitor of differentiation 1 & EID1 & 2.0 & 2.1 & 2.0 \\
\hline 2625 & GATA binding protein 3 & GATA3 & 2.0 & 1.6 & 1.6 \\
\hline 3398 & inhibitor of DNA binding 2, dominant negative helix-loop-helix protein & ID2 & 1.6 & 1.4 & 2.2 \\
\hline 23658 & LSM5 homolog, U6 small nuclear RNA associated (S. cerevisiae) & LSM5 & 1.7 & 1.8 & 2.0 \\
\hline 63931 & mitochondrial ribosomal protein S14 & MRPS14 & 1.9 & 2.4 & 2.2 \\
\hline 5936 & RNA binding motif protein 4 & RBM4 & 1.7 & 2.4 & 2.1 \\
\hline \multirow[t]{2}{*}{6591} & snail homolog 2 (Drosophila) & SNAI2 & 1.9 & 2.2 & 1.7 \\
\hline & Immune response/Response to virus & & & & \\
\hline 23586 & DEAD (Asp-Glu-Ala-Asp) box polypeptide 58 & DDX58 & 2.9 & 3.3 & 3.9 \\
\hline 79132 & DEXH (Asp-Glu-X-His) box polypeptide 58 & $\mathrm{DHX58}$ & 2.1 & 2.2 & 2.3 \\
\hline 10561 & interferon-induced protein 44 & $\mathrm{IF|} \mid 44$ & 2.1 & 2.7 & 2.8 \\
\hline 64135 & interferon induced with helicase $C$ domain 1 & $\mathrm{IFIH} 1$ & 2.0 & 2.2 & 2.3 \\
\hline 3434 & interferon-induced protein with tetratricopeptide repeats 1 & IFIT1 & 5.2 & 5.6 & 6.0 \\
\hline 3433 & interferon-induced protein with tetratricopeptide repeats 2 & IFIT2 & 3.1 & 3.7 & 4.2 \\
\hline 3437 & interferon-induced protein with tetratricopeptide repeats 3 & IFIT3 & 5.4 & 5.5 & 5.5 \\
\hline 9636 & ISG15 ubiquitin-like modifier & ISG15 & 2.2 & 2.6 & 2.1 \\
\hline 8638 & 2'-5'-oligoadenylate synthetase-like & OASL & 8.8 & 8.8 & 10.3 \\
\hline 445347 & TCR gamma alternate reading frame protein & TARP & 1.9 & 3.0 & 1.1 \\
\hline 6967 & T cell receptor gamma constant 2 & TRGC2 & 2.1 & 3.4 & 1.2 \\
\hline \multirow[t]{2}{*}{56829} & zinc finger $\mathrm{CCCH}$-type, antiviral 1 & ZC3HAV1 & 2.9 & 2.9 & 3.2 \\
\hline & Cell signalling & & & & \\
\hline 3641 & insulin-like 4 (placenta) & INSL4 & 2.4 & 2.7 & 2.5 \\
\hline 5122 & proprotein convertase subtilisin/kexin type 1 & PCSK1 & 2.8 & 2.8 & 2.5 \\
\hline \multirow[t]{2}{*}{25780} & RAS guanyl releasing protein 3 (calcium and DAG-regulated) & RASGRP3 & 1.6 & 2.1 & 1.8 \\
\hline & Nucleosome assembly & & & & \\
\hline 94239 & H2A histone family, member $V$ & H2AFV & 1.9 & 2.0 & 1.9 \\
\hline 8334 & histone cluster 1, H2ac & HIST1H2AC & 2.1 & 2.0 & 2.0 \\
\hline 8329 & histone cluster 1, H2ag & HIST1H2AG & 1.6 & 2.2 & 1.7 \\
\hline \multirow[t]{2}{*}{8349} & histone cluster 2, H2be & $\mathrm{HIST} 2 \mathrm{H} 2 \mathrm{BE}$ & 1.7 & 2.2 & 1.6 \\
\hline & Regulation of cell proliferation & & & & \\
\hline 2247 & fibroblast growth factor 2 (basic) & FGF2 & 3.4 & 3.5 & 3.7 \\
\hline 10216 & proteoglycan 4 & PRG4 & 1.7 & 2.2 & 1.7 \\
\hline \multirow[t]{2}{*}{5920} & retinoic acid receptor responder (tazarotene induced) 3 & RARRES3 & 2.3 & 2.4 & 2.5 \\
\hline & Apoptosis & & & & \\
\hline \multirow[t]{2}{*}{8743} & tumor necrosis factor (ligand) superfamily, member 10 & TNFSF10 & 2.5 & 2.9 & 2.6 \\
\hline & Cell cycle & & & & \\
\hline \multirow[t]{2}{*}{10083} & Usher syndrome 1 C (autosomal recessive, severe) & USH1C & 2.0 & 2.0 & 1.7 \\
\hline & Transport & & & & \\
\hline 57101 & anoctamin 2 & ANO2 & 1.9 & 2.1 & 2.0 \\
\hline 6337 & sodium channel, nonvoltage-gated 1 alpha & SCNN1A & 2.4 & 2.1 & 2.4 \\
\hline 6717 & sorcin & SRI & 2.3 & 2.3 & 2.6 \\
\hline
\end{tabular}


Table 2 Genes downregulated in the total RNA fraction in the presence of wild-type and mutant Tax proteins (Continued)

\begin{tabular}{|c|c|c|c|c|c|}
\hline & Ubiquitin & & & & \\
\hline 51191 & hect domain and RLD 5 & HERC5 & 4.9 & 5.0 & 5.7 \\
\hline \multirow[t]{2}{*}{55008} & hect domain and RLD 6 & HERC6 & 2.2 & 2.5 & 2.2 \\
\hline & Others/Unknown & & & & \\
\hline 83990 & BRCA1 interacting protein C-terminal helicase 1 & BRIP1 & 1.4 & 2.1 & 1.8 \\
\hline 79940 & chromosome 6 open reading frame 155 & C6orf155 & 1.5 & 2.1 & 1.5 \\
\hline 1601 & disabled homolog 2, mitogen-responsive phosphoprotein (Drosophila) & DAB2 & 2.2 & 2.3 & 2.2 \\
\hline 55601 & DEAD (Asp-Glu-Ala-Asp) box polypeptide 60 & DDX60 & 3.7 & 4.1 & 4.3 \\
\hline 2335 & fibronectin 1 & FN1 & 2.0 & 2.5 & 1.8 \\
\hline 23387 & SIK family kinase 3 & KIAA0999 & 1.2 & 1.2 & 2.2 \\
\hline 54809 & sterile alpha motif domain containing 9 & SAMD9 & 1.8 & 2.0 & 2.4 \\
\hline 6414 & selenoprotein $\mathrm{P}$, plasma, 1 & SEPP1 & 2.1 & 2.1 & 2.2 \\
\hline 8470 & sorbin and $\mathrm{SH} 3$ domain containing 2 & SORBS2 & 2.2 & 2.4 & 2.4 \\
\hline
\end{tabular}

overexpressed in the presence of $\operatorname{Tax}_{\mathrm{D} 247 \mathrm{G}}$ (Figure 5D). From these results, we confirmed that the regulation of genes in bovine cells expressing Tax was similar to the microarray results observed in human cells.

\section{Discussion}

Using interesting mutant forms of the BLV Tax protein with elevated $\left(\operatorname{Tax}_{\mathrm{D} 247 \mathrm{G}}\right)$ or reduced $\left(\mathrm{Tax}_{\mathrm{S} 240 \mathrm{P}}\right)$ transactivation activity in the replication and propagation of BLV [14], we identified cellular genes regulated by Tax protein by a large-scale host cell gene-profiling approach using human cDNA microarrays. Our results lead to 3 major conclusions as follows. (1) Several alterations in gene expression were observed after the expression of wild-type and mutant Tax proteins, including genes involved in transcription/translation/RNA processing, signal transduction, cell growth, apoptosis, stress response, and immune response. This clearly showed that BLV Tax protein has multiple biological effects on various cellular environments via the direct or indirect interaction of Tax with cellular partners. (2) Microarray data revealed that although all Tax proteins can induce gene expression changes in HeLa cells, the number and level of changes differ among the 3 Tax proteins. Particularly, $\operatorname{Tax}_{\mathrm{D} 247 \mathrm{G}}$ could induce high levels and large numbers of host gene expression changes, contrary to $\mathrm{Tax}_{\mathrm{S} 240 \mathrm{~B}}$ which induced very low levels and small numbers of gene expression changes, suggesting a correlation between gene expression and the transactivation activity of these mutants, as previously reported [8,14]. (3) The most interesting outcome of this study is the discovery that Tax and its mutants induced downregulation of expression of genes involved in the innate immune response. Moreover, genes related to the cellular stress response are also upreglated by Tax and this finding is

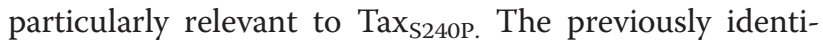
fied functions of BLV Tax are the activation of viral transcription $[2,4]$, modulation of cellular genes related to the regulation of cell growth such as c-fos [8], induction of transformation and immortalization [10], regulation of apoptosis [16], inhibition of DNA repair [13] and promotion of cell survival $[11,17]$. Therefore, these alterations in gene expression may suggest the presence of novel functions of the BLV Tax protein that are related with immune responses and stress responses.

Previously, we identified a series of mutant BLV Tax proteins, including $\operatorname{Tax}_{\mathrm{D} 247 \mathrm{G}}$ and $\mathrm{Tax}_{\mathrm{S} 240 \mathrm{~B}}$ which exhibit strikingly enhanced ability to stimulate or reduce viral LTR-directed transcription than the wild-type protein [8]. All of the mutants have at least 1 amino acid substitution between amino acids 240 and 265, and the CRE motif in the BLV LTR is sufficient for transactivation by the Tax mutants. Transient expression analysis revealed that $\operatorname{Tax}_{\mathrm{D} 247 \mathrm{G}}$, which had the strongest transactivation activity, more strongly increased the production of viral protein and particles from a defective recombinant proviral clone of BLV than the wild-type Tax did; conversely, $\operatorname{Tax}_{\mathrm{S} 240 \mathrm{P}}$ was unable to induce the release of viral particles. The present study shows that for half of the genes listed in Table 1, $\operatorname{Tax}_{\mathrm{D} 247 \mathrm{G}}$ induced higher gene expression than $\operatorname{Tax}_{\mathrm{WT}}$ and $\mathrm{Tax}_{\mathrm{S} 240 \mathrm{P}}$ did, and for many of these genes, with exceptions for genes related with stress responses, were expressed at the lowest levels in $\mathrm{Tax}_{\mathrm{S} 240 \mathrm{P}}$-transfected cells. These results indicate that in addition to the transactivation activity of BLV LTR, the expression of cellular genes might be limited or negatively regulated by the region of the BLV Tax protein between amino acids 240 and 265 and that the substitution D247G might act to circumvent this inhibitory activity. Furthermore, $\operatorname{Tax}_{\mathrm{D} 247 \mathrm{G}}$, but not $\operatorname{Tax}_{\mathrm{S} 240 \mathrm{~B}}$, was found to 
Table 3 Genes involved in signaling pathways regulated by wild-type and mutant Tax proteins $(p<0.05) *$

\begin{tabular}{|c|c|c|c|}
\hline Significant Pathway & $\operatorname{Tax}_{W T}$ & $\operatorname{Tax}_{S 240 P}$ & $\operatorname{Tax}_{\mathrm{D247G}}$ \\
\hline Direct p53 effectors & $\begin{array}{l}\text { DUSP1, DUSP5, GDF15, } \\
\text { HSPA1A, JUN, LIF }\end{array}$ & $\begin{array}{l}\text { BDKRB2, DUSP1, DUSP5, GDF15, } \\
\text { HSPA1A, JUN, LIF, SNAI2, SPP1 }\end{array}$ & $\begin{array}{l}\text { DUSP1, DUSP5, GDF15, } \\
\text { HSPA1A, JUN, LIF, SPP1 }\end{array}$ \\
\hline $\begin{array}{l}\text { Validated transcriptional targets of AP1 } \\
\text { family members Fra1 and Fra2 }\end{array}$ & $\begin{array}{l}\text { FOS, FOSL1, GATA3, JUN, } \\
\text { LIF, PLAUR }\end{array}$ & FOS, FOSL1, IL8, JUN, LIF & FOS, FOSL1, JUN, LIF \\
\hline IL1-mediated signaling events & DUSP1, FOS, FOSL1, GATA3, JUN & DUSP1, FOS, FOSL1, IL8, JUN & DUSP1, FOS, FOSL1, JUN \\
\hline BMP receptor signalling & DUSP1, FOS, FOSL1, GATA3, JUN & DUSP1, FOS, FOSL1, IL8, JUN & DUSP1, FOS, FOSL1, JUN \\
\hline p38 MAPK signaling pathway & DUSP1, FOS, FOSL1, GATA3, JUN & DUSP1, FOS, FOSL1, IL8, JUN & DUSP1, FOS, FOSL1, JUN \\
\hline Regulation of p38-alpha and p38-beta & DUSP1, FOS, FOSL1, GATA3, JUN & DUSP1, FOS, FOSL1, IL8, JUN & DUSP1, FOS, FOSL1, JUN \\
\hline IL12-mediated signaling events & ETV5, FOS, GATA3, JUN & ETV5, FOS, IL12A, JUN & ETV5, FOS, JUN \\
\hline $\begin{array}{l}\text { Role of Calcineurin-dependent NFAT } \\
\text { signaling in lymphocytes }\end{array}$ & FOS, FOSL1, GATA3, JUN & FOS, FOSL1, IL8, JUN & FOS, FOSL1, JUN \\
\hline $\begin{array}{l}\text { Calcineurin-regulated NFAT-dependent } \\
\text { transcription in lymphocytes }\end{array}$ & FOS, FOSL1, GATA3, JUN & FOS, FOSL1, IL8, JUN & FOS, FOSL1, JUN \\
\hline FOXM1 transcription factor network & ETV5, FOS, HSPA1A & ETV5, FOS, HSPA1A & ETV5, FOS, HSPA1A \\
\hline xef;ve CD4+ T cells & FOS, FOSL1, JUN & FOS, FOSL1, JUN & FOS, FOSL1, JUN \\
\hline CXCR4-mediated signaling events & FOS, FOSL1, JUN & FOS, FOSL1, JUN & FOS, FOSL1, JUN \\
\hline Glucocorticoid receptor signaling & FOS, GATA3, JUN & FOS, IL8, JUN & \\
\hline ATF-2 transcription factor network & DUSP1, DUSP5, JUN & DUSP1, DUSP5, IL8, JUN & DUSP1, DUSP5, HES1, JUN \\
\hline JNK signaling in the CD4+ TCR pathway & FOSL1, JUN & FOS, FOSL1, JUN & FOS, FOSL1, JUN \\
\hline Ras signaling in the CD4+ TCR pathway & FOS, FOSL1, JUN & FOS, FOSL1, JUN & FOS, FOSL1, JUN \\
\hline xef;ve CD8+ T cells & FOS, FOSL1, JUN & FOS, FOSL1, JUN & FOS, FOSL1, JUN \\
\hline Calcium signaling in the CD4+ TCR pathway & FOS, FOSL1, JUN & FOS, FOSL1, JUN & FOS, FOSL1, JUN \\
\hline $\begin{array}{l}\text { Regulation of Wnt-mediated beta catenin } \\
\text { signaling and target gene transcription }\end{array}$ & CYR61, JUN & IL8, JUN, SNAI2 & CYR61, ID2, JUN \\
\hline IL2-mediated signaling events & FOS, JUN & FOS, JUN & FOS, JUN \\
\hline ErbB2/ErbB3 signaling events & FOS JUN & FOS, JUN & FOS, JUN \\
\hline BCR signaling pathway & FOS, JUN & FOS, JUN & FOS, JUN \\
\hline IL12 signaling mediated by STAT4 & ETV5, JUN & ETV5, JUN & ETV5, JUN \\
\hline PDGFR-alpha signaling pathway & FOS, JUN & FOS, JUN & FOS, JUN \\
\hline Integrins in angiogenesis & CD44, FGF2 & CD44, FGF2, SPP1 & CD44, FGF2, SPP1 \\
\hline amb2 Integrin signalling & CYR61, PLAUR & & \\
\hline
\end{tabular}

*Up- or downregulated genes are represented by regular or italic characters, respectively.

activate other retroviral enhancers that are not activated or are only very slightly activated by the wild-type protein [14]. Moreover, $\operatorname{Tax}_{\mathrm{D} 247 \mathrm{G}}$ transfection resulted in remarkably increased levels of endogenous c-fos mRNA in both human and bovine cell lines [8]. Conversely, the wild-type Tax protein cannot activate the expression of human c-fos, indicating that wild-type BLV Tax might discriminate between human and bovine c-fos promoter sequences. Interestingly, we found that $\operatorname{Tax}_{\mathrm{D} 247 \mathrm{G}}$ regulated more genes involved in transcription, signal transduction, immune responses, cell growth, apoptosis, cell adhesion, transport, metabolic processes, phosphorylation, and other functions than $\mathrm{Tax}_{\mathrm{WT}}$ and $\mathrm{Tax}_{\mathrm{S} 240 \mathrm{P}}$ did. By contrast, the expression of heat-shock proteins (HSPs) such as DNAJB1, HSPA1A, and HSPA6, which are upregulated when cells are exposed to elevated temperatures or other stress [19], is significantly increased in the presence of $\operatorname{Tax}_{\mathrm{S} 240 \mathrm{P}}$ compared with that in the presence of other Tax proteins, indicating that BLV Tax may directly or indirectly be involved in stress response. These findings raised the possibility that the target sequence specificity of BLV Tax might be limited by the region of the protein between amino acids 240-265. Thus, the mutant proteins might have the ability to activate various cellular genes that might be barely activated, if at all, by wild-type Tax. Therefore, mutant forms of the BLV Tax protein, such as $\operatorname{Tax}_{\mathrm{D} 247 \mathrm{G}}$ and $\operatorname{Tax}_{\mathrm{S} 240}$, might be useful tools for elucidating the mechanism of known and novel functions induced by Tax expression. Our data also demonstrate the significant differences in 


\section{A}

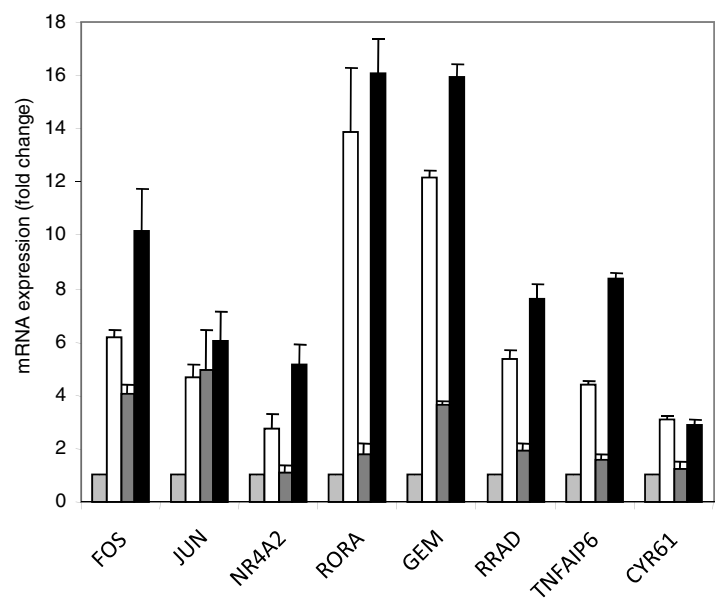

B

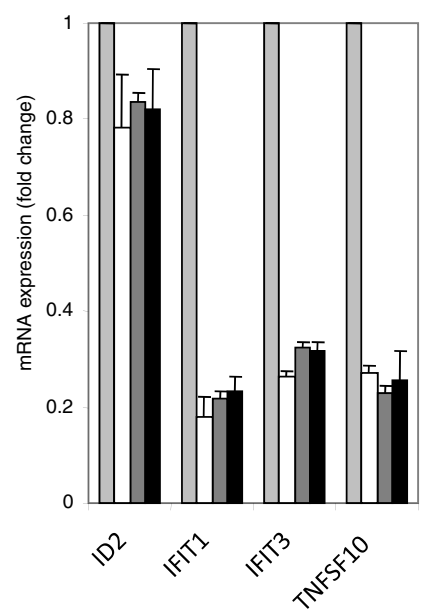

C

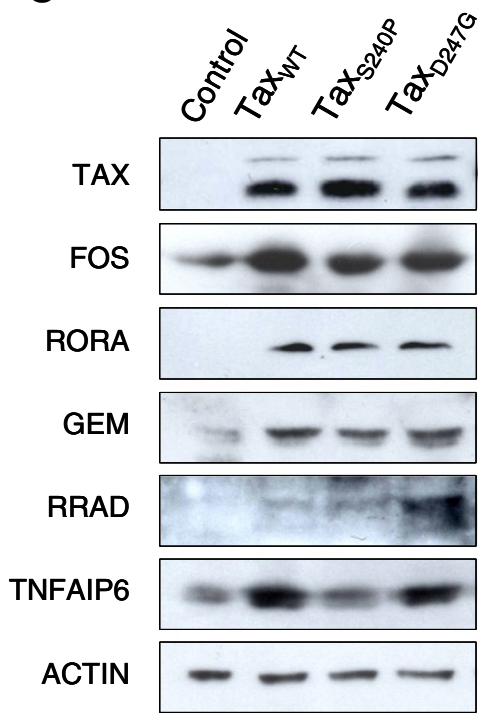

Figure 4 Validation of differentially expressed genes at the RNA and protein levels in HeLa cells. Differential expression of up- (A) or downregulated (B) genes in HeLa cells transfected with pCAGGS encoding Flag-tagged Tax proteins (Tax $x_{W T}$, open column; Tax $x_{5240}$, shaded column; Tax ${ }_{D 247 G}$, black column) or the control PCAGGS (light column) was validated by real-time RT-PCR. The bars indicate the fold change expression of the genes regulated by Tax. Data were normalized to GAPDH mRNA expression. The results represent the mean of 2 samples from 1 experiment. (C) Protein expressions of Tax, Fos, Rora, Rrad, Gem, and Tnfaip6 were validated by western blotting. Actin was used as a control.

the activating potential of $\operatorname{Tax}_{\mathrm{WT}}$, $\operatorname{Tax}_{\mathrm{D} 247 \mathrm{G}}$, and $\operatorname{Tax}_{\mathrm{S} 240}$, given that global changes in celluar gene expression are likely to critical to the transforming activity of these Tax mutants.

Our microarray data and qRT-PCR analysis clearly revealed that Tax transfection resulted in overexpression of FOS, and its mRNA expression level was much higher in bovine cells than in human cells. Western blotting also revealed the overexpression of FOS in the presence of Tax in both bovine 23CLN cells and HeLa cells. Furthermore, musculoaponeurotic fibrosarcoma (MAF) proteins, such as MAFB and MAFF, and JUN were significantly upregulated in the presence of Tax proteins (Table 1). Moreover, ATF-2 transcriptional factor network was significantly detected as the Tax-related signaling pathway by GeneSpring software (Table 3). It is well known that FOS, JUN, MAF, and ATF belong to the activator protein 1 (AP-1) transcription factor family [20]. AP-1 is a dimeric complex composed of JUN, FOS, MAF, and ATF protein families. This AP-1 complex can form many different combinations of heterodimers and homodimers, and different AP-1 dimers control transcriptional activation or suppression of 
A
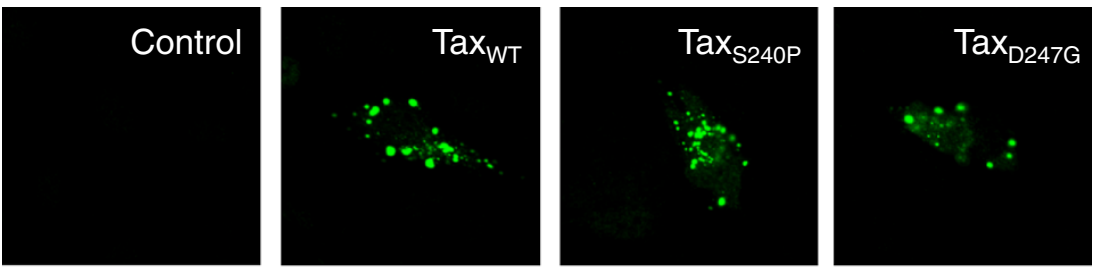

B

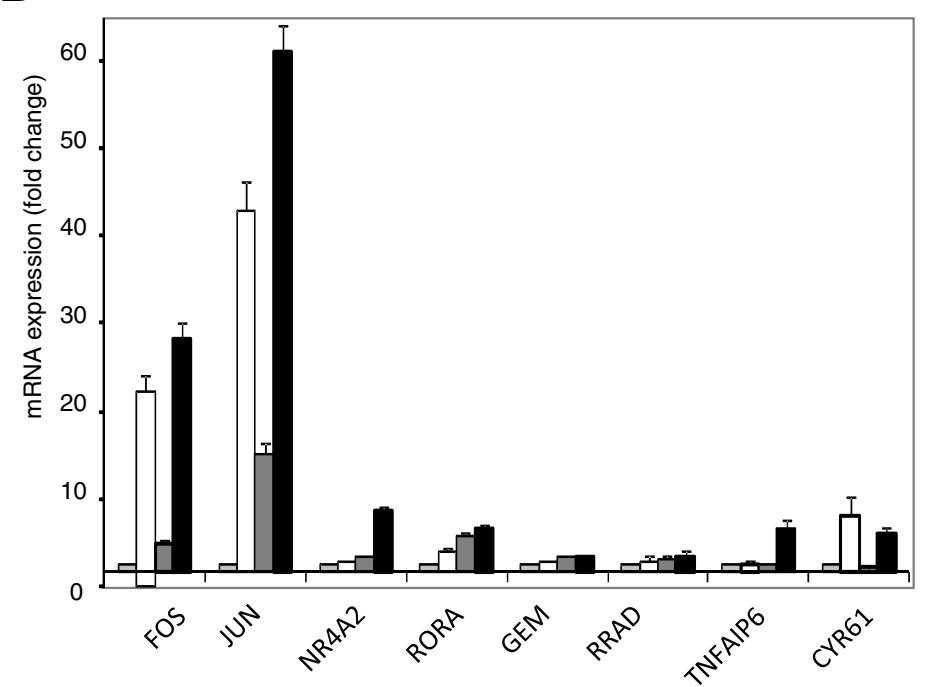

C

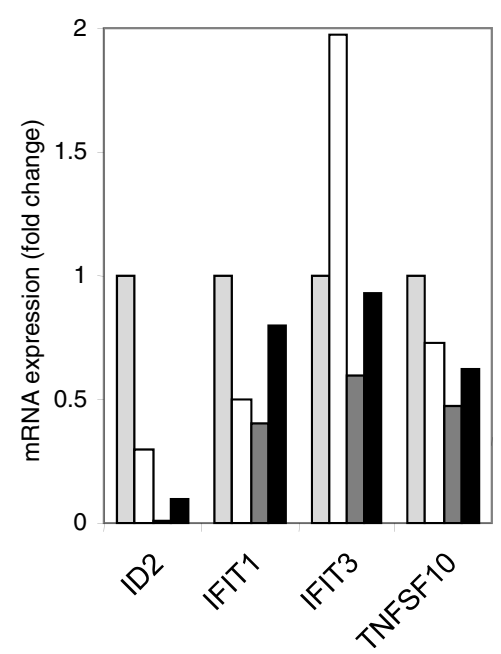

D

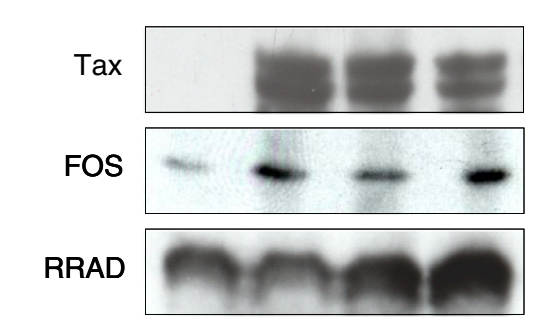

TNFAIP6

Actin
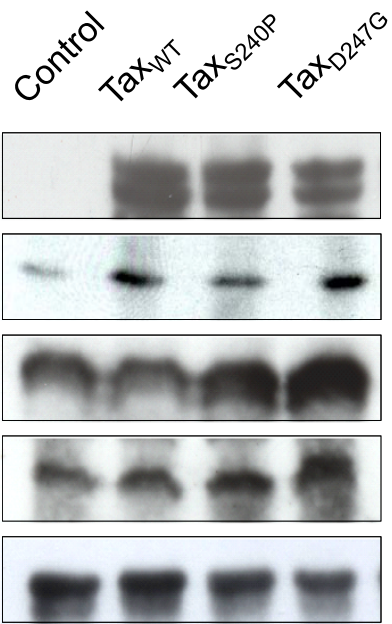

Figure 5 Validation of differentially expressed genes at the RNA and protein levels in bovine 23CLN cells. 23CLN cells were transfected with pCAGGS encoding Flag-tagged Tax proteins (Tax $w_{W}$, open column; Tax $x_{5240}$, shaded column; Tax ${ }_{\text {D247G, }}$ black column) or the control pCAGGS (light column). Thereafter, $24 \mathrm{~h}$ after transfection, cells were subjected to confocal laser-scanning analysis to detect localization (A) and to real-time RT-PCR (B and $\mathbf{C}$ ) and western blotting (D) to validate in bovine cells differential expression of cellular genes had altered after expression of wild-type and mutant Tax proteins in HeLa cells. The bars indicate the fold change expression of up- (B) or downregulated (C) genes regulated by Tax. Data were normalized to GAPDH mRNA expression. The results represent the mean of 2 samples from 1 experiment. (D) The protein expression of Tax and Fos, Rrad, and Tnfaip6 was validated by western blotting. Actin was used as a control. 
a variety of genes involved in the regulation of proliferation, differentiation, apoptosis, and transformation. Some members of the CREB protein families are also part of AP-1 complexes. Indeed, CREM, which is member of the CREB family, and ETS oncogene transcription family member ETV5 [21], which is known to cooperate with AP-1, were upregulated by Tax protein (Table 1). As shown in Table 3, signaling pathways regulated by Tax appeared to be involved in many transcriptional factor networks related to AP-1, such as Wnt-mediated signaling, MAP kinase signaling, IL1-, IL-2-, and IL12-mediated signaling, calcium signaling, and RAS signaling. These results were supported by previous results that the expression of the FOS gene is modulated by BLV Tax protein $[8,12,22]$, and in addition, BLV Tax protein could mediate transactivation of the viral genome through increased binding of the cellular proteins CREB, ATF-1, and ATF-2 to the TxREs $[6,23]$. Furthermore, results were confirmed by studies that reported that HTLV-1-Tax induced the expression of various family members of AP-1 such as c-JUN, JUN-D, c-FOS, and FRA-1 in T cells at the level of transcription through the AP-1-binding site, and upregulated genes contributed to the initial steps of the transformation process [24]. Thus, our findings raise the possibility that Tax mainly activates AP-1 signaling pathways via interactions with other transcriptional pathways, thereby stimulating the production of viral transcripts and induction of cellular genes.

The upregulation of AP-1 via direct overexpression or oncogenic RAS was found to correlate with a positive effect on cell transformation [25]. We showed that Tax protein activates nucleotide-binding proteins (G-Protein) such as GNB5 [26], GNG4 [27], RGS2 [28], and RGS16 [29] and GTP-binding proteins such as GEM [30] and RRAD [31]. Ras-related GTP-binding proteins comprise a superfamily consisting of many members that play important roles in cell proliferation and differentiation [32], cell cycle regulation [33], and glucose transport into cells [31,34]. It is known that these Ras-related GTP-binding proteins are linked with the AP-1 pathway. Interestingly, there is increasing evidence that the aberrant activity of numerous members of the Ras superfamily of small GTPases contributes to cancer growth, invasion, and metastasis [35]; as an example, RRAD overexpression in tumor tissue has been associated with poor prognosis among breast cancer patients [36]. Previously, Tax was reported to cooperate with the Ha-ras oncogene to induce the full transformation of cells that form tumors when it was injected into nude mice [10]. Thus, our results suggest a compromise of RAS superfamily such as GEM and RRAD expression in the mechanism leading to tumorigenesis by Tax.

Arguably the most surprising and significant finding of this study is that Tax protein transfection resulted in the up- and downregulation of genes related to the immune response, suggesting a novel function of BLV Tax protein, which can regulate immune response. In addition, all Tax variants down-regulated the expression of the T-cell specific factor GATA3, a notable difference with HTLV-1 Tax which cooperates together with ETS1/2 and GATA3 to activate the production of IL-5 [37]. The downregulated genes mainly belonged to the interferon family of anti-viral factors, such as IFI44, IFIH1, IFIT1, IFIT2, IFIT3, and ISG15. Interferons have emerged as major components of the innate immune system, and they are recognized for their antiviral function in addition to their antiproliferative and immunomodulatory effects on cells [38]. For BLV, IFNY has mainly been detected to suppress viral replication [39-41]. In human immunodeficiency virus type 1 (HIV-1), IFNs have been implicated in blocking both early and late stages of the HIV-1 lifecycle [42,43]. IFIT1, an interferon-stimulated gene (ISG), has also been implicated in the antiviral actions of IFNs[44] against hepatitis C virus, West Nile virus, lymphocytic choriomeningitis virus, parainfluenza 1 virus, vesicular stomatitis virus, and encephalomyocarditis virus [45-47]. It has also been reported that ISG15 plays an important role in inhibiting bovine immunodeficiency virus replication in fetal bovine lung cells, and its expression has been associated with antiviral function [48]. IFIT3 was recently described as a key element of the antiproliferative and antiviral activity of IFN [49-51]. Because these molecules have a primary role in antiviral function and we showed that they were all downregulated at similar levels by three Tax proteins in human and bovine cells except for up-regulation of IFIT3 gene by $\mathrm{Tax}_{\mathrm{WT}}$ in bovine $23 \mathrm{CLN}$ cells, it appears that Tax suppresses the innate immune response to promote persistence and transmission of BLV. Indeed, we previously found no significant differences in the viral load and the expression of viral RNA for 28 weeks between sheep experimentally injected with BLVs that encode the wildtype and mutant $\operatorname{Tax}_{\mathrm{D} 247 \mathrm{G}}$ proteins, in contrast to in vitro that $\operatorname{Tax}_{\mathrm{D} 247 \mathrm{G}}$ produced more viral proteins and particles, and was transmitted very effectively [15], suggesting that $\mathrm{Tax}_{\mathrm{WT}}$ and $\mathrm{Tax}_{\mathrm{D} 247 \mathrm{G}}$ which possess different transactivation abilities for BLV LTR and cellular protooncogene c-fos, might suppress similarly expression of genes involved in the immune response in vivo as well as our microarray results, thereby promoting expansion and infection of BLV on equal level in vivo.

The Tax-upregulated gene related to the immune response is TNFAIP6 (tumour necrosis factor alpha inductor protein 6; TSG-6). This gene is not constitutively expressed in healthy adult tissues, but it has been observed in physiological and pathological contexts that are associated with inflammation and tissue remodeling [52,53]; for example, TNFAIP6 has been observed in 
cultured human uterine cervical fibroblasts, in which it is upregulated in response to IL-1 and TNF- $\alpha$ [54]. In BLV replication, an important role for TNF- $\alpha$ has been suggested in the elimination of BLV during the early stage of infection and in the progression of disease during the lymphocytosis stage [41,55-57]. Moreover, it has clearly been demonstrated that the lack of TNF- $\alpha$ expression enhanced the persistence of BLV infection in TNF- $\alpha^{-1-}$ mice [58]. In contrast to TNF $\alpha$, the role of TNFAIP6 in BLV infection is unknown. Nevertheless, as TNFAIP6 is upregulated in response to TNF- $\alpha$, there is a possibility that TNFAIP6 may regulate the disease progression of BLV-induced leukemogenesis. Importantly, HTLV-1 dampens the TNF $\alpha$ response to promote persistence of HTLV-1 infection [59]. Moreover, TNF $\alpha$ shows promise as part of a combined therapy for the treatment of HTLV-1 induced adult T cell Leukemia [60]. Therefore, our data are likely to be important in understanding both BLV and HTLV-1 persistence in infected hosts and suggest possible strategies to improve therapies for BLV and HTLV-1-induced disease. Collectively, further investigation is required to define the role of Tax in immune responses and the function of the genes related to immune responses in BLV and HTLV-1 pathogeneses.

Genes that are up- or downregulated in the presence of Tax are likely to play important roles in transcription, signal transduction, cell growth, apoptosis, stress responses, and immune responses. Although these results were obtained using a human cDNA microarray system, we believe that the use of mutant Tax proteins $\left(\operatorname{Tax}_{\mathrm{D} 247 \mathrm{G}}\right.$ and $\left.\operatorname{Tax}_{\mathrm{S} 240 \mathrm{P}}\right)$ in human cells is the best available system to begin preliminary studies on the effects of Tax on transformation during BLV and HTLV-1 infections. Indeed, although it may be noted to show the different expression patterns in several factors, such as FOS, JUN, RORA, GEM, RRAD, TNFAIP6 and IFIT3 genes in human and bovine cells, we could validate that the regulation of genes in bovine cells expressing Tax was similar to the microarray results observed in human cells in this study. However, we also assume that a number of genes is not equally expressed in different cell lines and/or in vivo. At this point, the extent of these effects and the manner in which they may be interrelated with the induction of BLV and HTLV-1 induced lymphoma or the regulation of disease progression are not known. A detailed study addressing the direct and indirect effects of Tax-mediated transformation is needed to gain a better understanding of the contribution of Tax to BLV and HTLV-1 pathogenesis. Our findings also lend some additional support to the hypothesis that viruses have evolved mechanisms of changing the host cellular milieu to facilitate viral replication and pathogenesis strategies that can be investigated at a mechanistic level, and our data suggest additional avenues for the development of novel antiretroviral therapeutics.

\section{Conclusion}

By undertaking a comparative analysis of the BLV Tax protein with elevated $\left(\operatorname{Tax}_{\mathrm{D} 247 \mathrm{G}}\right)$ or reduced $\left(\operatorname{Tax}_{\mathrm{S} 240 \mathrm{P}}\right)$ transactivation activity, we found that Tax exerts a significant impact on cellular functions as diverse as transcription, translation, RNA processing, signal transduction, cell growth, apoptosis, stress response and immune response. Importantly, to our knowledge, our study is the first report that shows the extent to which BLV Tax regulates the innate immune response and it is likely that this tactic ensures ongoing viral replication and viral persistence even in the face of a strong host immune response. From our data, we suggest that understanding the molecular mechanisms used by BLV and HTLV-1 to thwart the immune response will lead to new avenues for the development of novel and effective antiretroviral therapeutics.

\section{Methods}

\section{Cells and transfection}

Human cervical HeLa and bovine lymph node 23CLN cells were maintained in DMEM medium (Invitrogen) supplemented with $10 \%$ heat-inactivated fetal bovine serum (FBS) and 100 units/mL penicillin/streptomycin (Sigma). For transient transfection, cells were transfected with Tax wild-type or mutant expression vectors by using FuGENE HD (Roche) according to the manufacturer's instructions.

\section{Construction of plasmids}

The Tax genes were amplified from pME18Neo encoding wild-type $\left(\operatorname{Tax}_{\mathrm{WT}}\right)$ and mutant (S240P $\left(\operatorname{Tax}_{\mathrm{S} 240 \mathrm{P}}\right)$ and D247G $\left(\operatorname{Tax}_{\mathrm{D} 247 \mathrm{G}}\right)$ ) Tax proteins by using the primers BTaxF (5'-AACTCGAGGCCACCATGGCAAGTGTTGT TGGTTGGGGGCC-3') and BTaxR (5'-AAGCGCCGCTC ACTTGTCGTCATCGTCTTTGTAGTCAAAAAGGCGG GAGAGCC-3'). The underlined sequences in the forward and reverse primers correspond to the restriction sites for XhoI and NotI, respectively, and the Flag sequence was included at the $3^{\prime}$ end of all Tax genes. PCR products were then introduced into the XhoI and NotI sites of the pCAGGS mammalian vector [61]. The pGV-BLTR reporter plasmid has been described previously [14]. The pRL-SV40 plasmid (Promega), which encodes a Renilla luciferase gene, was used for normalization of the efficiencies of transfection.

\section{Luciferase assay}

HeLa and 23CLN cells were seeded into 24-well plates $24 \mathrm{~h}$ before transfection at a density of $1 \times 10^{5}$ cells per well. Cells were transfected with $1 \mu \mathrm{g}$ of each Tax vector, 
$0.5 \mu \mathrm{g}$ of pGV-BLTR, and $0.5 \mu \mathrm{g}$ of pRL-SV40 by using FuGENE HD, according to the manufacturer's instructions. Luciferase activity was measured $24 \mathrm{~h}$ after transfection by using the Dual-Luciferase Reporter Assay System (Promega) according to the manufacturer's protocol. The firefly luciferase reporter and the Renilla luciferase reactions were measured using a multilabel counter (Model 1420, Wallac Arvo, Perkin Elmer Life Sciences). Relative luciferase activity was calculated as firefly/Renilla luciferase activity, and the luciferase activity of each construct was compared with that of the pGV-BLTR vector. All experiments were conducted in duplicate at 3 different times.

\section{Immunofluorescence}

HeLa and 23CLN cells were seeded onto 22-mmdiameter coverslips in 24-well plates $24 \mathrm{~h}$ before transfection, at a density of $1 \times 10^{5}$ cells/well. After $24 \mathrm{~h}$ of transfection with each Tax vector or control vector, cells were washed twice with phosphate-buffered saline (PBS), fixed in $3.7 \%$ formaldehyde, permeabilized using $0.2 \%$ Triton X-100, and stained using an anti-Flag M2 MAb (Sigma), followed by an anti-mouse $\operatorname{IgG}_{1}$ Alexa 488 antibody (Molecular Probes). Nuclei were stained using Hoechst 33342 (Sigma). Subcellular localization was determined using an Olympus fluorescence microscope (Olympus, FV1000).

\section{RNA extraction}

After $24 \mathrm{~h}$ of transfection with each Tax vector or control vector, some cells were analyzed by Immunofluorescence. RNA was isolated from total cell extracts of HeLa or 23CLN cells by using an RNeasy Mini Kit (Qiagen) according to the manufacturer's instructions at $30 \mathrm{~h}$ posttransfection when the expression efficiency was greater than $30 \%$ in all transfections. For high quality of the RNA, the protocol included the remove of residual DNA in the sample. RNA was quantified using a spectrophotometer and then stored at $-80^{\circ} \mathrm{C}$. For gene-chip analysis, the quality of RNA was tested using the Agilent Bioanalyser (Agilent Technologies) runs.

\section{Microarray analysis}

RNA samples were run once on microarray using the HGU133A 2.0 Affymetrix chip. Microarray hybridization and fluorescence detection were performed as described in the Affymetrix Gene-Chip Expression Analysis Technical Manual. Microarray data analyses were subjected to bioinformatics process to identify statistically significant changes in gene expression between samples by using GeneSpring GX 11.0 software (Agilent Technologies). Microarray data have been deposited in NCBI's Gene Expression Omnibus and assigned GEO Series accession number GSE35823. We obtained fold changes in gene expression, hierarchical clustering, and gene ontology annotations, and revealed which pathways were significantly up- or downregulated $(\mathrm{p}<0.05)$.

\section{qRT-PCR}

After $30 \mathrm{~h}$ of transfection with each Tax vector or control vector, cells were lysed, and total RNA was prepared using the RNeasy Mini Kit (Qiagen). RT-PCR was performed using specific primers for the targets and OneStep SYBR Green PCR mix (Takara), according to the manufacturer's manual. qRT-PCR was performed using a Prism 7500 sequence detection system (Applied Biosystems). Samples were run in duplicates and all data were normalized to GAPDH mRNA expression.

\section{Western blot analysis}

After $30 \mathrm{~h}$ of transfection with each Tax vector or control vector, cells were lysed, separated through a 6-10\% sodium dodecyl (SDS)-polyacrylamide gel, and then transferred to a PVDF membrane (Immobilon-P, Millipore Corp.) using a Trans-blot SD semi-dry transfer cell (Bio-Rad). After the transfer, the membranes were blocked in a 5\% non-fat dry milk in PBS and $0.1 \%$ Tween-20 and then incubated with a 1:1000 dilution of primary antibody anti-Flag M2 MAb (Sigma) or a 1:300 dilution in the case of FOS (K-25), RORA (X-23), GEM (G-1), RRAD (D-15), TSG-6 (N-20), or Actin (c-11) antibodies; all antibodies were obtained from Santa Cruz Biotechnology. Thereafter, the membranes were washed and incubated either with anti-mouse, anti-rabbit, or anti-goat horseradish peroxidase-conjugated secondary antibody (Jackson, Immuno Research) and developed using the SuperSignal West Pico Chemiluminescent substrate Kit (Pierce).

\section{Competing interests}

The authors declare that they have no competing interests.

\section{Authors' contributions}

MA participated in all experiments, analyzed the data, and drafted the manuscript. ET participated in some experiments and analyzed some data. YA conceived the study, participated in the experiments, participated in the experimental design, coordinated the experiments, and drafted the manuscript. All authors read and approved the final manuscript.

\section{Acknowledgements}

We thank Mr. Kazunori Yamada for help of manuscript preparation and submission in BMC Genomics; Dr. Shin-nosuke Takeshima for submission of microarray data in the NCBI's Gene Expression Omnibus and kind help of preparation of manuscript; Mrs. Mayuko Jimba for help of manuscript preparation; and other members of the Viral Infectious Diseases Unit, RIKEN, for kind help and suggestions. We thank Mr. Keisuke Fukumoto for excellent technical assistance and kind help. We are grateful to the Support Unit for Bio-material Analysis, RIKEN BSI Research Resources Center for assistance with the microarray and sequence analyses. This work was supported by Grantsin-Aid for Scientific Research (A and B) from the Japan Society for the Promotion of Science (JSPS) and by a Grant of Program for the Promotion of Basic and Applied Research for Innovations in Bio-oriented Industry. 
Received: 3 October 2011 Accepted: 16 March 2012

Published: 28 March 2012

\section{References}

1. Burny A, Cleuter Y, Kettmann R, Mammerickx M, Marbaix G, Portetelle D, Van den Broeke A, Willems L, Thomas R: Bovine leukemia: facts and hypotheses derived from the study of an infectious cancer. Adv Vet Sci Comp Med 1988, 32:149-170.

2. Derse D: Bovine leukemia virus transcription is controlled by a virus-encoded trans-acting factor and by cis-acting response elements. J Virol 1987, 61(8):2462-2471.

3. Derse D: Trans-acting regulation of bovine leukemia virus mRNA processing. J Virol 1988, 62(4):1115-1119.

4. Willems L, Gegonne A, Chen G, Burny A, Kettmann R, Ghysdael J: The bovine leukemia virus p34 is a transactivator protein. EMBO J 1987 , 6(11):3385-3389

5. Adam E, Kerkhofs P, Mammerickx M, Burny A, Kettmann R, Willems L: The CREB, ATF-1, and ATF-2 transcription factors from bovine leukemia virus-infected B lymphocytes activate viral expression. J Virol 1996, 70(3):1990-1999.

6. Adam E, Kerkhofs P, Mammerickx M, Kettmann R, Burny A, Droogmans L, Willems L: Involvement of the cyclic AMP-responsive element binding protein in bovine leukemia virus expression in vivo. J Virol 1994, 68(9):5845-5853.

7. Boros IM, Tie F, Giam CZ: Interaction of bovine leukemia virus transactivator Tax with bZip proteins. Virology 1995, 214(1):207-214.

8. Tajima S, Aida Y: Mutant tax protein from bovine leukemia virus with enhanced ability to activate the expression of c-fos. J Virol 2002, 76(5):2557-2562

9. Kerkhofs $P$, Heremans $H$, Burny A, Kettmann R, Willems L: In vitro and in vivo oncogenic potential of bovine leukemia virus G4 protein. J Virol 1998, 72(3):2554-2559.

10. Willems L, Heremans H, Chen G, Portetelle D, Billiau A, Burny A, Kettmann R: Cooperation between bovine leukaemia virus transactivator protein and Ha-ras oncogene product in cellular transformation. EMBO J 1990, 9(5):1577-1581.

11. Szynal M, Cleuter $Y$, Beskorwayne $T$, Bagnis $C$, Van Lint $C$, Kerkhofs $P$, Burny A, Martiat P, Griebel P, Van den Broeke A: Disruption of B-cell homeostatic control mediated by the BLV-Tax oncoprotein: association with the upregulation of $\mathrm{Bcl}-2$ and signaling through NF-kappaB. Oncogene 2003, 22(29):4531-4542

12. Klener P, Szynal M, Cleuter Y, Merimi M, Duvillier H, Lallemand F, Bagnis C, Griebel $P$, Sotiriou C, Burny A, et al: Insights into gene expression changes impacting B-cell transformation: cross-species microarray analysis of bovine leukemia virus tax-responsive genes in ovine B cells. J Virol 2006, 80(4):1922-1938.

13. Philpott SM, Buehring GC: Defective DNA repair in cells with human T-cell leukemia/bovine leukemia viruses: role of tax gene. J Natl Cancer Inst 1999, 91(11):933-942.

14. Tajima S, Aida Y: The region between amino acids 245 and 265 of the bovine leukemia virus (BLV) tax protein restricts transactivation not only via the BLV enhancer but also via other retrovirus enhancers. J Virol 2000 74(23):10939-10949.

15. Tajima S, Takahashi M, Takeshima SN, Konnai S, Yin SA, Watarai S, Tanaka Y, Onuma M, Okada K, Aida Y: A mutant form of the tax protein of bovine leukemia virus (BLV), with enhanced transactivation activity, increases expression and propagation of BLV in vitro but not in vivo. J Virol 2003, 77(3):1894-1903.

16. Takahashi M, Tajima S, Okada K, Davis WC, Aida Y: Involvement of bovine leukemia virus in induction and inhibition of apoptosis. Microb Infect/Institut Pasteur 2005, 7(1):19-28.

17. Takahashi M, Tajima S, Takeshima SN, Konnai S, Yin SA, Okada K, Davis WC, Aida $Y$ : Ex vivo survival of peripheral blood mononuclear cells in sheep induced by bovine leukemia virus (BLV) mainly occurs in CD5- B cells that express BLV. Microb Infect/Institut Pasteur 2004, 6(6):584-595.

18. Roussev RK, Shikova E, Portetelle D, Alexandrov I, Dimitrov P, Polianova M, Ganchev G: Expression of BLV Tax protein in lymphocytes and COS cells. Exp Pathol Parasitol 2003, 6:81-87.

19. Hunt C, Morimoto Rl: Conserved features of eukaryotic hsp70 genes revealed by comparison with the nucleotide sequence of human hsp70. Proc Natl Acad Sci U S A 1985, 82(19):6455-6459.
20. Wagner EF, Eferl R: Fos/AP-1 proteins in bone and the immune system. Immunol Rev 2005, 208:126-140.

21. Euhus DM, Bu D, Xie XJ, Sarode V, Ashfaq R, Hunt KK, Xia W, O'Shaughnessy JA, Grant M, Arun BK, et al: Tamoxifen Downregulates Ets-oncogene Family Members ETV4 and ETV5 in Benign Breast Tissue: Implications for Durable Risk Reduction. Cancer Prev Res (Phila) 2011, 4(11):1852-1862.

22. Katoh I, Yoshinaka $Y$, Ikawa $Y$ : Bovine leukemia virus trans-activator p38tax activates heterologous promoters with a common sequence known as a CAMP-responsive element or the binding site of a cellular transcription factor ATF. EMBO J 1989, 8(2):497-503.

23. Nguyen TL, Calomme C, Wijmeersch G, Nizet S, Veithen E, Portetelle D, de Launoit Y, Burny A, Van Lint C: Deacetylase inhibitors and the viral transactivator TaxBLV synergistically activate bovine leukemia virus gene expression via a cAMP-responsive element- and cAMP-responsive element-binding protein-dependent mechanism. J Biol Chem 2004, 279(33):35025-35036.

24. Hall WW, Fujii M: Deregulation of cell-signaling pathways in HTLV-1 infection. Oncogene 2005, 24(39):5965-5975.

25. Eferl R, Wagner EF: AP-1: a double-edged sword in tumorigenesis. Nat Rev Cancer 2003, 3(11):859-868.

26. Witherow DS, Slepak VZ: A novel kind of G protein heterodimer: the G beta5-RGS complex. Receptors Channels 2003, 9(3):205-212.

27. Kalyanaraman S, Copeland NG, Gilbert DG, Jenkins NA, Gautam N: Structure and chromosomal localization of mouse $\mathrm{G}$ protein subunit gamma 4 gene. Genomics 1998, 49(1):147-151.

28. Kehrl JH, Sinnarajah S: RGS2: a multifunctional regulator of G-protein signaling. Int J Biochem Cell Biol 2002, 34(5):432-438.

29. Doi M, Ishida A, Miyake A, Sato M, Komatsu R, Yamazaki F, Kimura I, Tsuchiya S, Kori H, Seo K, et al: Circadian regulation of intracellular G-protein signalling mediates intercellular synchrony and rhythmicity in the suprachiasmatic nucleus. Nat Commun 2011, 2:327.

30. Maguire J, Santoro T, Jensen P, Siebenlist U, Yewdell J, Kelly K: Gem: an induced, immediate early protein belonging to the Ras family. Science 1994, 265(5169):241-244

31. Moyers JS, Bilan PJ, Reynet C, Kahn CR: Overexpression of Rad inhibits glucose uptake in cultured muscle and fat cells. J Biol Chem 1996, 271(38):23111-23116.

32. Lange-Carter CA, Johnson GL: Ras-dependent growth factor regulation of MEK kinase in PC12 cells. Science 1994, 265(5177):1458-1461.

33. Ren M, Drivas G, D'Eustachio P, Rush MG: Ran/TC4: a small nuclear GTP-binding protein that regulates DNA synthesis. J Cell Biol 1993 120(2):313-323.

34. Cormont M, Bortoluzzi MN, Gautier N, Mari M, van Obberghen E, Le Marchand-Brustel Y: Potential role of Rab4 in the regulation of subcellular localization of Glut4 in adipocytes. Mol Cell Biol 1996, 16(12):6879-6886.

35. Vigil D, Cherfils J, Rossman KL, Der CJ: Ras superfamily GEFs and GAPs: validated and tractable targets for cancer therapy? Nat Rev Cancer 2010, 10(12):842-857.

36. Tseng YH, Vicent D, Zhu J, Niu Y, Adeyinka A, Moyers JS, Watson PH, Kahn CR: Regulation of growth and tumorigenicity of breast cancer cells by the low molecular weight GTPase Rad and nm23. Cancer Res 2001, 61(5):2071-2079.

37. Blumenthal SG, Aichele G, Wirth T, Czernilofsky AP, Nordheim A, Dittmer J: Regulation of the human interleukin-5 promoter by Ets transcription factors. Ets1 and Ets2, but not Elf-1, cooperate with GATA3 and HTLV-I Tax1. J Biol Chem 1999, 274(18):12910-12916.

38. Hu R, Gan Y, Liu J, Miller D, Zoon KC: Evidence for multiple binding sites for several components of human lymphoblastoid interferon-alpha. J Biol Chem 1993, 268(17):12591-12595

39. Keefe RG, Ferrick DA, Stott JL: Cytokine transcription in lymph nodes of cattle in different stages of bovine leukemia virus infection. Vet Immunol Immunopathol 1997, 59(3-4):271-283.

40. Sentsui H, Murakami K, Inoshima Y, Yokoyama T, Inumaru S: Anti-viral effect of recombinant bovine interferon gamma on bovine leukaemia virus. Cytokine 2001, 16(6):227-231.

41. Usui $T$, Konnai $\mathrm{S}$, Ohashi $\mathrm{K}$, Onuma M: Expression of tumor necrosis factor-alpha in lgM + B-cells from bovine leukemia virus-infected lymphocytotic sheep. Vet Immunol Immunopathol 2006, 112(3-4):296-301. 
42. Agy MB, Acker RL, Sherbert $\mathrm{CH}$, Katze MG: Interferon treatment inhibits virus replication in HIV-1- and SIV-infected CD4+ T-cell lines by distinct mechanisms: evidence for decreased stability and aberrant processing of HIV-1 proteins. Virology 1995, 214(2):379-386.

43. Barr SD, Smiley JR, Bushman FD: The interferon response inhibits HIV particle production by induction of TRIM22. PLoS Pathog 2008, 4(2):e1000007.

44. Li Y, Li C, Xue P, Zhong B, Mao AP, Ran Y, Chen H, Wang YY, Yang F, Shu HB: ISG56 is a negative-feedback regulator of virus-triggered signaling and cellular antiviral response. Proc Natl Acad Sci U S A 2009, 106(19):7945-7950.

45. Guo J, Peters KL, Sen GC: Induction of the human protein P56 by interferon, double-stranded RNA, or virus infection. Virology 2000, 267(2):209-219.

46. Wacher C, Muller M, Hofer MJ, Getts DR, Zabaras R, Ousman SS, Terenzi F, Sen GC, King NJ, Campbell IL: Coordinated regulation and widespread cellular expression of interferon-stimulated genes (ISG) ISG-49, ISG-54, and ISG-56 in the central nervous system after infection with distinct viruses. J Virol 2007, 81(2):860-871.

47. Wang C, Pflugheber J, Sumpter R Jr, Sodora DL, Hui D, Sen GC, Gale M Jr: Alpha interferon induces distinct translational control programs to suppress hepatitis C virus RNA replication. J Virol 2003, 77(7):3898-3912.

48. Liu C, Li X, Yao X, Kong X, Qiao W, Geng Y: Bovine ISG15: an antiviral and inducible protein in BIV infected fetal bovine lung cells. Virol J 2010, 7:134.

49. Lou YJ, Pan XR, Jia PM, Li D, Xiao S, Zhang ZL, Chen SJ, Chen Z, Tong JH: IRF-9/STAT2 [corrected] functional interaction drives retinoic acid-induced gene $\mathrm{G}$ expression independently of STAT1. Cancer Res 2009, 69(8):3673-3680.

50. Schmeisser H, Mejido J, Balinsky CA, Morrow AN, Clark CR, Zhao T, Zoon KC: Identification of alpha interferon-induced genes associated with antiviral activity in Daudi cells and characterization of IFIT3 as a novel antiviral gene. J Virol 2010, 84(20):10671-10680.

51. Xiao S, Li D, Zhu HQ, Song MG, Pan XR, Jia PM, Peng LL, Dou AX, Chen GQ, Chen SJ, et al: RIG-G as a key mediator of the antiproliferative activity of interferon-related pathways through enhancing p21 and p27 proteins. Proc Natl Acad Sci U S A 2006, 103(44):16448-16453.

52. Glant TT, Kamath RV, Bardos T, Gal I, Szanto S, Murad YM, Sandy JD, Mort JS, Roughley PJ, Mikecz K: Cartilage-specific constitutive expression of TSG-6 protein (product of tumor necrosis factor alpha-stimulated gene 6) provides a chondroprotective, but not antiinflammatory, effect in antigen-induced arthritis. Arthritis Rheum 2002, 46(8):2207-2218.

53. Wisniewski HG, Vilcek J: TSG-6: an IL-1/TNF-inducible protein with anti-inflammatory activity. Cytokine Growth Factor Rev 1997, 8(2):143-156.

54. Shimizu D, Hosoya N, Ogawa M, Konishi Y, Sato H, Hirano H, Tanaka T: Expression of tumor necrosis factor-alpha stimulated gene- 6 mRNA in cultured human uterine cervical fibroblasts. Acta Obstet Gynecol Scand 2005, 84(8):780-787.

55. Kabeya H, Fukuda A, Ohashi K, Sugimoto C, Onuma M: Tumor necrosis factor alpha and its receptors in experimentally bovine leukemia virus-infected sheep. Vet Immunol Immunopathol 2001, 81(1-2):129-139.

56. Kabeya H, Ohashi K, Oyunbileg N, Nagaoka Y, Aida Y, Sugimoto C, Yokomizo Y, Onuma M: Up-regulation of tumor necrosis factor alpha mRNA is associated with bovine-leukemia virus (BLV) elimination in the early phase of infection. Vet Immunol Immunopathol 1999 68(2-4):255-265

57. Konnai S, Usui T, Ikeda M, Kohara J, Hirata T, Okada K, Ohashi K, Onuma M: Imbalance of tumor necrosis factor receptors during progression in bovine leukemia virus infection. Virology 2005, 339(2):239-248.

58. Muller C, Coffey TJ, Koss M, Teifke JP, Langhans W, Werling D: Lack of TNF alpha supports persistence of a plasmid encoding the bovine leukaemia virus in TNF(-/-) mice. Vet Immunol Immunopathol 2003, 92(1-2):15-22

59. Yang YC, Hsu TY, Lin RH, Su IJ, Chen JY, Yang CS: Resistance to tumor necrosis factor-alpha-induced apoptosis in human T-lymphotropic virus type l-infected T cell lines. AIDS Res Hum Retroviruses 2002, 18(3):207-212.

60. Matsuda T, Almasan A, Tomita M, Uchihara JN, Masuda M, Ohshiro K, Takasu N, Yagita H, Ohta T, Mori N: Resistance to Apo2 ligand (Apo2L)/tumor necrosis factor-related apoptosis-inducing ligand (TRAIL)-mediated apoptosis and constitutive expression of Apo2L/TRAIL in human T-cell leukemia virus type 1-infected T-cell lines. J Virol 2005, 79(3):1367-1378.

61. Niwa H, Yamamura K, Miyazaki J: Efficient selection for high-expression transfectants with a novel eukaryotic vector. Gene 1991, 108(2):193-199.

doi:10.1186/1471-2164-13-121

Cite this article as: Arainga et al:: Identification of bovine leukemia virus tax function associated with host cell transcription, signaling, stress response and immune response pathway by microarray-based gene expression analysis. BMC Genomics 2012 13:121.

\section{Submit your next manuscript to BioMed Central and take full advantage of:}

- Convenient online submission

- Thorough peer review

- No space constraints or color figure charges

- Immediate publication on acceptance

- Inclusion in PubMed, CAS, Scopus and Google Scholar

- Research which is freely available for redistribution

Submit your manuscript at www.biomedcentral.com/submit
C) Biomed Central 